OPEN ACCESS

Edited by:

Junhua Peng,

Center for Life Sci \& Tech of China National Seed Group Co. Ltd., China

Reviewed by:

Xiaoli Jin,

Zhejiang University, China

Man Zhou,

University of Minnesota, USA

*Correspondence:

Yan L

yanli1@njau.edu.cn

Specialty section:

This article was submitted to

Plant Biotechnology,

a section of the journal

Frontiers in Plant Science

Received: 07 December 2016 Accepted: 09 February 2017

Published: 24 February 2017

Citation:

Li S, Cong Y, Liu Y, Wang T, Shuai Q, Chen N, Gai J and Li Y (2017)

Optimization of

Agrobacterium-Mediated

Transformation in Soybean.

Front. Plant Sci. 8:246

doi: 10.3389/fp/s.2017.00246

\section{Optimization of Agrobacterium-Mediated Transformation in Soybean}

\author{
Shuxuan Li, Yahui Cong, Yaping Liu, Tingting Wang, Qin Shuai, Nana Chen, Junyi Gai and \\ Yan $L i$ * \\ National Key Laboratory of Crop Genetics and Germplasm Enhancement, Key Laboratory for Biology and Genetic \\ Improvement of Soybean (General, Ministry of Agriculture), National Center for Soybean Improvement, Jiangsu Collaborative \\ Innovation Center for Modern Crop Production, Nanjing Agricultural University, Nanjing, China
}

High transformation efficiency is a prerequisite for study of gene function and molecular breeding. Agrobacterium tumefaciens-mediated transformation is a preferred method in many plants. However, the transformation efficiency in soybean is still low. The objective of this study is to optimize Agrobacterium-mediated transformation in soybean by improving the infection efficiency of Agrobacterium and regeneration efficiency of explants. Firstly, four factors affecting Agrobacterium infection efficiency were investigated by estimation of the rate of GUS transient expression in soybean cotyledonary explants, including Agrobacterium concentrations, soybean explants, Agrobacterium suspension medium, and co-cultivation time. The results showed that an infection efficiency of over $96 \%$ was achieved by collecting the Agrobacterium at a concentration of $\mathrm{OD}_{650}=0.6$, then using an Agrobacterium suspension medium containing $154.2 \mathrm{mg} / \mathrm{L}$ dithiothreitol to infect the half-seed cotyledonary explants (from mature seeds imbibed for 1 day), and co-cultured them for 5 days. The Agrobacterium infection efficiencies for soybean varieties Jack Purple and Tianlong 1 were higher than the other six varieties. Secondly, the rates of shoot elongation were compared among six different concentration combinations of gibberellic acid $\left(\mathrm{GA}_{3}\right)$ and indole-3-acetic acid (IAA). The shoot elongation rate of 34 and $26 \%$ was achieved when using the combination of $1.0 \mathrm{mg} / \mathrm{L} \mathrm{GA} 3$ and $0.1 \mathrm{mg} / \mathrm{L}$ IAA for Jack Purple and Tianlong 1, respectively. This rate was higher than the other five concentration combinations of $\mathrm{GA}_{3}$ and IAA, with an 18 and $11 \%$ increase over the original laboratory protocol (a combination of $0.5 \mathrm{mg} / \mathrm{L} \mathrm{GA} 3$ and $0.1 \mathrm{mg} / \mathrm{L}$ IAA), respectively. The transformation efficiency was 7 and 10\% for Jack Purple and Tianlong 1 at this optimized hormone concentration combination, respectively, which was 2 and 6\% higher than the original protocol, respectively. Finally, GUS histochemical staining, PCR, herbicide (glufosinate) painting, and QuickStix Kit for Liberty Link (bar) were used to verify the positive transgenic plants, and absolute quantification PCR confirmed the exogenous gene existed as one to three copies in the soybean genome. This study provides an improved protocol for Agrobacterium-mediated transformation in soybean and a useful reference to improve the transformation efficiency in other plant species.

Keywords: Agrobacterium, efficiency, half-seed explants, infection, regeneration, shoot elongation, soybean transformation 


\section{INTRODUCTION}

Soybean [Glycine max (L.)] is one of the most important oil crops and a significant source of protein for food and feed in the world. Soybean seeds are not only rich in essential amino acids, but also rich in dietary minerals, vitamins, unsaturated fatty acids, and isoflavones, which are implicated as beneficial food for human health (Han et al., 2003). Genetically modified (GM) soybean is one of the earliest introduced GM crops for commercial cultivation and the largest GM crop in terms of acreage planted worldwide (Yang et al., 2012). Studies have shown that the new GM crop varieties with important application values must be selected from hundreds, thousands, or even tens of thousands transformation events (Wang et al., 2006). On the other hand, although the soybean genome sequence has been released (Schmutz et al., 2010), the functions of most soybean genes are unknown. Therefore, an efficient and stable genetic transformation method is an important prerequisite to study gene functions in soybean and develop new soybean varieties by molecular breeding.

There are three main ways to deliver foreign DNA into host plants, including Agrobacterium-mediated transformation (Hinchee et al., 1988), particle bombardment (Mccabe et al., 1988), and pollen-tube pathway method (Shou et al., 2002). Agrobacterium tumefaciens is a gram-negative bacterium and widespread in soil. Agrobacterium can infect plants through its Ti plasmid, and its T-DNA can be integrated to the host plant genome and inherited by the offspring of host plant (Wu et al., 2005). Particle bombardment method can insert the exogenous DNA (which is attached to micron-sized metal particles) directly into the tissue cells using high-pressure helium gas (Liu et al., 2001). Due to the strong penetrating power of small particle, the exogenous DNA-metal particle can penetrate the cell wall and cell membrane into cells. Particle bombardment transformation makes the transfer of DNA is no longer restricted by species or genotypes, especially suitable for the species and genotypes which are not sensitive to Agrobacterium infection (Wang et al., 2002). However, the cost of particle bombardment transformation is high, and gene rearrangement and high copy numbers are often observed in transgenic plants using this method (Wang et al., 2009). Pollen-tube pathway method delivers the exogenous DNA into a zygote cell or early embryo cells of recipient plant through the pollen tube directly (Zhou et al., 1983), which does not need tissue culture process (Ren et al., 2012), and exogenous DNA can be transferred to host plants directly without vector construct (Xiao et al., 2007). But the exogenous gene needs to go through many barriers along pollen tube into the zygote, and can be destroyed by the nuclease in stigma. Therefore, it is difficult to get a stable transformation rate by this method (Shou et al., 2002; Dong et al., 2011).

About $85 \%$ of the transgenic plants are obtained using the Agrobacterium-mediated transformation method (Yu et al., 2010). Agrobacterium-mediated transformation is the best choice for plant transformation due to its simple operation, high reproducibility, low copy number, and low experimental cost. This method also can transfer a large fragment of foreign gene into the host plant genome. Agrobacterium-mediated transformation is also a preferred method in soybean. Hinchee et al. used soybean cotyledonary nodes as the explants to obtain transgenic soybean plants (Hinchee et al., 1988). From then on, many researchers used cotyledonary nodes as the explants for transformation (Di et al., 1996; Zhang et al., 1999). In addition to cotyledonary nodes, many other tissue types can be used as explants, such as primary leaf nodes, epicotyls, and hypocotyls, immature embryos, axillary buds, and stem tips. But the regeneration efficiency differed greatly among different explants. Cotyledonary nodes have a higher regeneration efficiency than other types of explants in soybean (Kim et al., 1990; Sato et al., 1993; Liu et al., 2004; Zhong and Que, 2009). In addition, using cotyledonary nodes as the explants has several other advantages. First, it is easy to obtain the cotyledonary nodes by germinating soybean seeds, which is not limited by the season. Second, the regeneration process is simple, including shoot induction, elongation and root induction. However, the transformation rate of this method is too low. Instead of germinating the soybean seeds to get cotyledonary nodes, Paz et al. imbibed mature soybean seeds for about $24 \mathrm{~h}$ to obtain the "half seeds" as the cotyledonary explants ( $\mathrm{Paz}$ et al., 2006). The overall average transformation efficiency was 3.8\% using this method, which was 1.5 times higher than using the cotyledonary nodes from the 5to 7-d-old seedlings (Paz et al., 2006), but still low compared with the transformation efficiency in other crops such as rice 23\% (Lin and Zhang, 2005; Ge et al., 2006) and maize 30-40\% (Ishida et al., 1996; Yang et al., 2006). The previous study indicates that the low shoot elongation rate during explants regeneration is a bottleneck for soybean transformation (Song et al., 2013).

During the transformation process, there are many factors affecting the efficiency. The general transformation process includes the following steps: obtain the explants after seed sterilization; infect explants with the Agrobacterium suspension liquid and co-cultivate them on the co-cultivation medium (CCM) with their adaxial side (flat side) upwards (Gao et al., 2015); transfer the Agrobacterium-infected explants to shoot induction medium (SIM); transfer the explants to shoot elongation medium (SEM); put the elongated shoots into rooting medium; eventually the plants were transferred to pots and grown to maturity (Figure 1). During this process, many factors such as type of explants, concentration of Agrobacterium for infection, co-cultivation time, and medium composition (including CCM, SIM, SEM, and rooting medium), will affect the transformation efficiency. The efficiencies of regeneration and transformation also varied among different soybean genotypes (Hinchee et al., 1988; Bailey and Parrott, 1993; Donaldson and Simmonds, 2000; Yang et al., 2016). The overall transformation efficiency depends on the efficiencies of Agrobacterium infection and explant regeneration.

Agrobacterium concentration is an important factor affecting its infection efficiency (Paz et al., 2006). Agrobacterium concentration reflects its growth status and the Agrobacterium during logarithmic growth phase is thought to have higher infection ability (Zhou et al., 2011). In the Vanda Kasem's Delight Orchid, the highest $\beta$-glucuronidase (GUS) expression in protocorm-like bodies was observed when the optical density at $600 \mathrm{~nm}\left(\mathrm{OD}_{600}\right)$ of Agrobacterium suspension was 0.8 


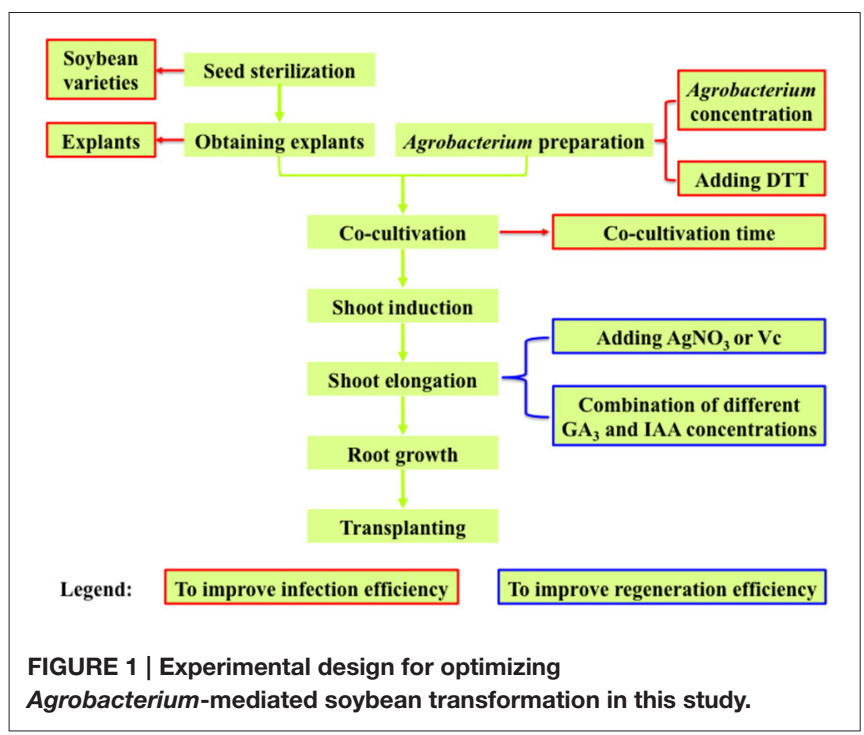

(Gnasekaran et al., 2014). In groundnut, the most suitable $\mathrm{OD}_{600}$ of Agrobacterium for infection was determined as 1.8 (Tiwari et al., 2015). The Agrobacterium concentration for infection of ramie was optimized as $\mathrm{OD}_{600}=0.6$ (An et al., 2014).

Plant hormones play important roles in explant regeneration during tissue culture, especially auxins, cytokinins, and gibberellins. Auxin was discovered as a phytohormone with the chemical structure of indole-3-acetic acid (IAA), and synthetic auxins such as indole-3-butyric acid (IBA), naphthalene acetic acid (NAA), and 2,4-dichlorophenoxyacetic acid (2,4-D) also have auxin activity, which promote cell elongation, plant growth, and development (Normanly, 1997). Cytokinins promote cytokinesis, differentiation and growth of various tissues (Letham, 1967). 6-benzylaminopurine (6-BA), kinetin (KT), zeatin (ZT) are synthetic cytokinins. In plant tissue culture, the concentrations of auxin and cytokinin affect the regeneration efficiency of explants (Skoog and Miller, 1957). Kumari et al. found that Murashige and Skoog (MS) medium (Murashige and Skoog, 1962) supplemented with $2 \mathrm{mg} / \mathrm{L} 6-\mathrm{BA}$ and $0.2 \mathrm{mg} / \mathrm{L}$ IAA was optimum for shoot regeneration in Bacopa monniera (Kumari et al., 2015). In groundnut, a high regeneration efficiency was achieved by adding $66.6 \mu \mathrm{M}$ 6-BA in the medium, while the highest number of shoot buds per explant was achieved by adding $20 \mu \mathrm{M}$ 6-BA and $10 \mu \mathrm{M}$ 2,4-D (Tiwari et al., 2015). The highest regeneration efficiency for cotyledonary nodes of Crambe was observed on basic medium with $0.5 \mu \mathrm{M}$ NAA and $2.2 \mu \mathrm{M}$ 6-BA (Qi et al., 2014).

Gibberellin (GA) is one of the most important hormones affecting plant growth and development (Hua and Irving, 2011). It not only promotes seed germination, hypocotyl elongation, xylem development, and internode elongation, but also induces the differentiation of flower buds (Yukika et al., 1997; Almqvist, 2003; Thomas and Sun, 2004). GA is necessary for stem elongation (Nishijima et al., 1997). A previous study showed that the highest number of shoots per explant and shoot elongation rate was obtained by using $3 \mathrm{mg} / \mathrm{L}$ 6-BA in combination with 0.5 $\mathrm{mg} / \mathrm{L} \mathrm{GA}_{3}$ during shoot induction stage in tea (Gonbad et al., 2014). MS medium supplemented with $1 \mathrm{mg} / \mathrm{L}$ 6-BA, $0.1 \mathrm{mg} / \mathrm{L}$ IBA, and $2 \mathrm{mg} / \mathrm{L} \mathrm{GA}_{3}$ promoted shoot elongation significantly in Cerasus campanulata (Wang and Huang, 2002). In sweet potato, the combination of $10 \mathrm{mg} / \mathrm{L} \mathrm{GA}_{3}$ and $1 \mathrm{mg} / \mathrm{L} \mathrm{6-BA}$ could give rise to significantly taller shoots $(20 \mathrm{~mm})$ compared to the rest of the treatments (Masekesa et al., 2016).

Callus browning is another problem to solve for Agrobacterium-mediated transformation. Explants will have defense response when infected by Agrobacterium. Then the protective layer is formed on the cell surface that results in browning or necrosis. In order to mitigate tissue browning in Agrobacterium-mediated transformation, researchers have concentrated on the antioxidants such as ascorbate $(\mathrm{Vc}), \alpha$-lipoic acid, $\alpha$-tocopherol, dithiothreitol (DTT), glutathione, L-cysteine (L-cys), polyvinylpolypyrrolidone (PVPP), and selenite (Dan, 2008). These antioxidants can reduce tissue browning of transformed cells and improve regeneration efficiency, thus enhancing transformation efficiency. A combination of $\mathrm{Vc}$, silver nitrate $\left(\mathrm{AgNO}_{3}\right)$ and cysteine improved Agrobacteriummediated transformation efficiency in sugar cane (Enríquez Obregón et al., 1998). Adding Vc to tissue culture medium can significantly reduce the degree of browning, and adding $\mathrm{AgNO}_{3}$ can not only reduce tissue browning effectively, but also improve the number of adventitious buds significantly in Zizyphus jujube (Huang et al., 2006). When $\mathrm{AgNO}_{3}$ and 6-BA were added in the culture medium during soybean transformation using hypocotyl as explants, the induction rate of adventitious buds was improved (five times higher than the control group) and the rate of hypocotyl browning was reduced (Wang and $\mathrm{Xu}$, 2008). Adding $\alpha$-lipoic acid significantly increased the induction rate of transgenic shoots in four crop species including soybean, wheat, tomato, and cotton (Dan et al., 2009). DTT has been found to play positive roles in plant transformation. In soybean, different concentrations of DTT and L-cys were added in the Agrobacterium re-suspension medium and CCM to inhibit the necrosis of explants (Olhoft and Somers, 2001; Li et al., 2008b; Zhang et al., 2016). When 0.1\% DTT was added in CCM, the regeneration efficiency increased from 8 to $22 \%$ in wheat ( $\mathrm{Yu}$ et al., 2005).

In this study, we tried to improve the Agrobacteriummediated transformation efficiency in soybean by improving the infection efficiency of Agrobacterium and regeneration efficiency of explants (shoot elongation rate). The Agrobacterium infection efficiencies were compared using different concentrations of Agrobacterium for infection, explants, Agrobacterium suspension medium, co-cultivation time, and soybean varieties. The rates of shoot elongation were evaluated by adding different concentration combinations of $\mathrm{GA}_{3}$ and IAA, as well as $\mathrm{AgNO}_{3}$ or $\mathrm{Vc}$ in the tissue culture medium. The Agrobacterium infection efficiency was estimated by the rate of GUS transient expression in soybean cotyledonary explants, and the rate of shoot elongation was investigated by the frequencies of elongated shoots. Finally, the transformation efficiency was calculated based on the number of positive transgenic soybean seedlings detected by different methods. The optimized protocol for Agrobacteriummediated transformation in this study would be helpful to further 
study gene functions in soybean and develop new varieties by molecular breeding.

\section{MATERIALS AND METHODS}

\section{Experimental Design}

As the overall transformation efficiency is largely determined by the efficiencies of Agrobacterium infection and explant regeneration (where shoot elongation rate is the bottleneck in soybean), we investigated the key factors affecting Agrobacterium infection efficiency including Agrobacterium concentrations, explants, Agrobacterium suspension medium, co-cultivation time, and soybean varieties (Figure 1, textboxes with red borders), and the major factors affecting the explant regeneration efficiency (shoot elongation rate) including different concentration combinations of $\mathrm{GA}_{3}$ and IAA in SEM as well as adding $\mathrm{AgNO}_{3}$ or Vc in SIM and SEM (Figure 1, textboxes with blue borders).

\section{Plant Materials}

Soybean varieties including Tianlong 1, Jack Purple, DLH, NN419, Williams 82, HZM, NN34, NN88-1 were used in this study. The seeds were provided by the National Center for Soybean Improvement at Nanjing Agricultural University, Nanjing, China.

\section{Agrobacterium Strain and Vector}

The A. tumefaciens strain EHA101 (Hood et al., 1986) and the binary plasmid pTF102 (Frame and Kan, 2002) were used in this study, which were kindly provided by Dr. Huixia Shou (Zhejiang University, China) and Dr. Kan Wang (Iowa State University, USA), respectively. The pTF102 vector contains a GUS gene (with intron) as the reporter gene, a bar gene as the selectable marker gene (conferring resistance to herbicide glufosinate), and an $\operatorname{aad} A$ gene for resistance to antibiotics spectinomycin.

\section{Agrobacterium Culture and Infection Medium}

To prepare the Agrobacterium infection medium, a single colony of $A$. tumefaciens strain EHA101/pTF102 was picked from the plate and put into $5 \mathrm{ml}$ liquid YEB (An et al., 1989, $5 \mathrm{~g} / \mathrm{L}$ $\mathrm{NaCl}, 10 \mathrm{~g} / \mathrm{L}$ peptone, $5 \mathrm{~g} / \mathrm{L}$ yeast extract) containing $25 \mathrm{mg} / \mathrm{L}$ chloramphenicol, $50 \mathrm{mg} / \mathrm{L}$ kanamycin, $50 \mathrm{mg} / \mathrm{L}$ streptomycin, and $100 \mathrm{mg} / \mathrm{L}$ spectinomycin, and cultured for $24 \mathrm{~h}$ at $28^{\circ} \mathrm{C}$ (250 rpm) to get the starter culture. Next, $200 \mathrm{ul}$ of the starter culture was transferred to $200 \mathrm{ml} \mathrm{YEB}$ culture and grown at $28^{\circ} \mathrm{C}$ $(250 \mathrm{rpm})$ in a shaker incubator until $\mathrm{OD}_{650}$ reached $0.6,0.8$, or 1.0. The Agrobacterium culture was collected and centrifuged at $5000 \mathrm{rpm}\left(22^{\circ} \mathrm{C}\right)$ for $10 \mathrm{~min}$, and then the pellet was resuspended using the liquid $\mathrm{CCM}$ until $\mathrm{OD}_{650}$ reached 0.7 . The re-suspended infection medium was shaken for $0.5 \mathrm{~h}$ (70 rpm, $22^{\circ} \mathrm{C}$ ) before use. The liquid CCM contains $1 / 10 \mathrm{X} \mathrm{B}_{5}$ basal medium (Gamborg and $\mathrm{Al}, 1968$ ) supplemented with $3.9 \mathrm{~g} / \mathrm{L} 2$ [N-morpholino] ethanesulfonic acid (MES), 3\% (30 g/L) sucrose, $\mathrm{pH}=5.4$ (adjusting by $\mathrm{KOH}$ ), $1.67 \mathrm{mg} / \mathrm{L} 6-\mathrm{BA}, 0.25 \mathrm{mg} / \mathrm{L} \mathrm{GA}_{3}$, $40 \mathrm{mg} / \mathrm{L}$ acetosyringone (AS), and DTT (0 or $154.2 \mathrm{mg} / \mathrm{L}$ ).

\section{The Process of Soybean Transformation}

The protocol for Agrobacterium-mediated soybean transformation in this study was based on a previous study (Paz et al., 2006) with modification, which is briefly summarized as the following steps (Figure 2).

\section{Explant Preparation, Agrobacterium Infection and Co-Cultivation}

The mature soybean seeds without any defects were wiped clean using a cotton cloth (wetted by $75 \%$ alcohol), and then surfacesterilized for 6 or $12 \mathrm{~h}$ with chlorine gas $(100 \mathrm{ml} \mathrm{NaClO}+$ $10 \mathrm{ml} \mathrm{HCl}$ or $100 \mathrm{ml} \mathrm{NaClO}+3.5 \mathrm{ml} \mathrm{HCl}$ ) in a tightly sealed chamber (Figure 2A). To get the half-seed cotyledonary explants, the sterilized seeds were soaked in sterile water at $23^{\circ} \mathrm{C}$ under dark for 16-18 h (Figure 2B). Then the imbibed seeds were longitudinally cut along the hilum using a scalpel, and the

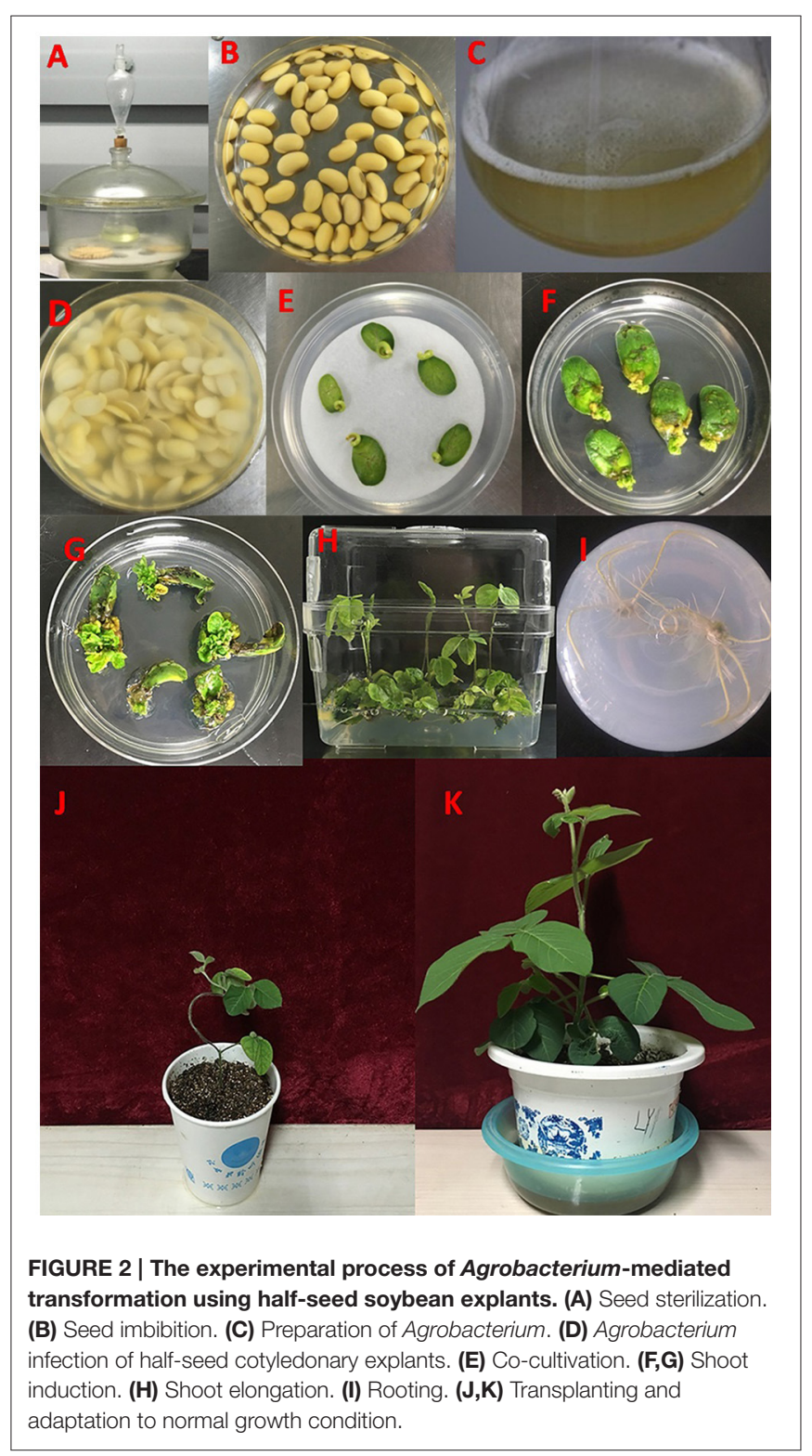


seed coats were removed. The hypocotyls were trimmed to 3 $\mathrm{mm}$. The half-seed cotyledonary explants or cotyledonary nodes from 1-, 3-, or 5-d-old seedlings were put in the prepared resuspended Agrobacterium infection medium (Figure 2C) for 30 min (Figure 2D). The Agrobacterium suspension medium was shaken during the period of infection to make the explants in well contact with the Agrobacterium liquid. After infection, five to seven explants (adaxial side up) were evenly placed on sterile filter paper over solid CCM in Petri dishes $(90 \mathrm{~mm}$ in diameter $\times 15$ $\mathrm{mm}$ deep), and co-cultivated at $23^{\circ} \mathrm{C}$ under a photoperiod of 16 h/8 h (light/dark) for 3-5 d (Figure 2E). The solid CCM contains $1 / 10 \mathrm{X} \mathrm{B}_{5}$ basal medium supplemented with $3.9 \mathrm{~g} / \mathrm{L} \mathrm{MES,} \mathrm{3 \%}$ $(30 \mathrm{~g} / \mathrm{L})$ sucrose, $0.5 \%(5 \mathrm{~g} / \mathrm{L})$ agrose (Biowest, Spain), $\mathrm{pH}=5.4$ (adjusting by $\mathrm{KOH}$ ), $1.67 \mathrm{mg} / \mathrm{L} 6-\mathrm{BA}, 0.25 \mathrm{mg} / \mathrm{L} \mathrm{GA}_{3}, 40 \mathrm{mg} / \mathrm{L}$ AS, $400 \mathrm{mg} / \mathrm{L}$ L-cys, $154.2 \mathrm{mg} / \mathrm{L}$ DTT, and $158 \mathrm{mg} / \mathrm{L}$ sodium thiosulfate.

\section{Tissue Culture and Transplanting}

After co-cultivation, the explants were inserted (tilting 45 degrees) in SIM with the adaxial side facing upward, and maintained in a walk-in chamber under the photoperiod of $16 \mathrm{~h} / 8 \mathrm{~h}$ (light/dark) and temperature of $23^{\circ} \mathrm{C}$ (Figures $2 \mathrm{~F}, \mathrm{G}$ ). The SIM contains $\mathrm{B}_{5}$ basal medium supplemented with $3 \%$ sucrose, $0.35 \%$ (3.5 g/L) phytagel (Sigma, USA), $0.58 \mathrm{~g} / \mathrm{L} \mathrm{MES,}$ $\mathrm{pH} 5.6,1.67 \mathrm{mg} / \mathrm{L}$ 6-BA, $50 \mathrm{mg} / \mathrm{L}$ cefotaxime (Cef), $500 \mathrm{mg} / \mathrm{L}$ carbenicillin (Carb), and $5 \mathrm{mg} / \mathrm{L}$ glufosinate (Sigma, USA). Two weeks later, the explants were transferred to fresh SIM. Four weeks after shoot induction, the explants were transferred to SEM, which contains MS basal medium (Murashige and Skoog, $1962)$ supplemented with $3 \%$ sucrose, $0.35 \%$ (3.5 g/L) phytagel (Sigma, USA), $0.58 \mathrm{~g} / \mathrm{L}$ MES, pH 5.6, $0.5 \mathrm{mg} / \mathrm{L} \mathrm{GA}, 0.1 \mathrm{mg} / \mathrm{L}$ IAA, $1 \mathrm{mg} / \mathrm{L}$ zeatin (ZR), $50 \mathrm{mg} / \mathrm{L}$ asparagine (Asp), $100 \mathrm{mg} / \mathrm{L}$ L-pyroglutamic acid (L-pyro), $75 \mathrm{mg} / \mathrm{L}$ Cef, $500 \mathrm{mg} / \mathrm{L} \mathrm{Carb}$, and $3 \mathrm{mg} / \mathrm{L}$ glufosinate. The explants were transferred to fresh SEM every two weeks until the elongated shoots reached $3 \mathrm{~cm}$ high (Figure 2H). Elongated shoots were placed into rooting medium ( $\mathrm{B}_{5}$ basal medium supplemented with $1.5 \%$ sucrose, $0.8 \%$ agar powder, $0.59 \mathrm{~g} / \mathrm{L}$ MES, pH 5.7, and $1 \mathrm{mg} / \mathrm{L}$ IBA), until the roots were developed to $2-3 \mathrm{~cm}$ in length (Figure 2I). Eventually the plants were transplanted in pots (soil: vermiculite $=1: 1$ ) and grown in greenhouse at $28 / 24^{\circ} \mathrm{C}$ with a photoperiod of $16 \mathrm{~h} / 8$ h (light/dark) until maturity (Figures 2J,K).

\section{Identification of Positive Transgenic Soybean Plants}

We used the following four methods to detect the positive transgenic soybean plants.

\section{GUS Histochemical Staining}

The young leaves of transgenic soybean plants were collected and submerged in GUS staining solution (Table S1) overnight in dark at $37^{\circ} \mathrm{C}$, then rinsed in $75 \%$ alcohol two or three times to remove chlorophyll (Jefferson et al., 1987). The tissues of positive transgenic plants would show blue color.

\section{Herbicide (glufosinate) Painting}

Half (along the midrib) of a leaf (the upper surface) was painted with $135 \mathrm{mg} / \mathrm{L}$ glufosinate using a swab, while a black line was drawn on the other half leaf to mark it as control. About seven days later, if the half leaf with glufosinate treatment is same as the control, the plant is tolerant to herbicide and therefore positive.

\section{PCR Assay}

Total genomic DNA was extracted using the CTAB method (Paterson et al., 1993). Gene specific primers were designed by NCBI Primer-BLAST (https://www.ncbi.nlm.nih.gov/tools/ primer-blast/), and were used to amplify the 1812 bp GUS fragment and $428 \mathrm{bp}$ bar fragment (Table S2). The PCR condition was set as the following: one cycle at $95^{\circ} \mathrm{C}$ for $3 \mathrm{~min}$, followed by 35 cycles of $95^{\circ} \mathrm{C}$ for $30 \mathrm{~s}, 56^{\circ} \mathrm{C}$ for $30 \mathrm{~s}, 72^{\circ} \mathrm{C}$ for $1 \mathrm{~min} 50 \mathrm{~s}$ (GUS), or $30 \mathrm{~s}$ (bar), and a final extension at $72^{\circ} \mathrm{C}$ for $5 \mathrm{~min}$. The amplified PCR products were visualized and photographed using the gel imaging system after electrophoresis on a $0.8 \%(\mathrm{w} / \mathrm{v})$ agarose gel containing $120 \mathrm{ul} / \mathrm{L}$ ethidium bromide.

\section{LibertyLink $^{\circledR}$ Strip (bar) Test}

Leaf tissue was put in an Eppendorf tube and grounded with 0.5 $\mathrm{ml}$ extraction buffer by a pestle. Then a LibertyLink ${ }^{\circledR}$ strip was inserted into the tube and waited for $10 \mathrm{~min}$. The appearance of a control line indicates the strip is functional and the second line (test line) indicates the sample is positive.

\section{Analysis of Gene Copy Number by Absolute Quantification PCR}

The copy number of bar gene integrated in the soybean genomic DNA was estimated by the ratio of exogenous target gene (bar)/internal reference gene (lectin), $\mathrm{X}_{0} / \mathrm{R}_{0}$, which could be calculated according to the formula: $\mathrm{X}_{0} / \mathrm{R}_{0}=$ $10^{[(\mathrm{Ct}, \mathrm{X}-\mathrm{IX}) / \mathrm{SX}]-[(\mathrm{Ct}, \mathrm{R}-\mathrm{IR}) / \mathrm{SR}]}$ (Weng et al., 2004), where $\mathrm{C}_{t, X}$ and $\mathrm{C}_{t, R}$ represents the $\mathrm{Ct}$ value of target gene (bar) and reference gene (lectin), respectively; IX and SX is the intercept and slope of the standard curve of the target gene, respectively; IR and SR is the intercept and slope of the standard curve of the reference gene, respectively. The stand curve was obtained by plotting the logarithms of the template DNA copy number (X axis) against the Ct values (Y axis) using a series of DNA template dilutions, where the template DNA copy number $=$ avogadro constant $(6.02$ $\left.\times 10^{23}\right) \times$ concentration of template DNA $(\mathrm{g} / \mathrm{ml}) /$ the relative molecular mass of template DNA ( $\mathrm{g} / \mathrm{mol})$, and the Ct values were obtained by absolute quantification PCR. The standard curves of the exogenous bar gene (on the positive plasmid) and the internal lectin gene (on the genomic DNA) were established respectively (Sambrook and Russell, 2001). The size of positive plasmid we used in this study is $11,622 \mathrm{bp}$, and the genome size of soybean is 1,150 Mb (Schmutz et al., 2010). Because two soybean varieties were used for transformation, the series dilutions of genomic DNA from the control plants of both Jack Purple and Tianlong 1, as well as the positive plasmid were made respectively to generate the standard curves.

Quantification PCR was performed on the LightCycler 480 (Roche, USA) to obtain the Ct values of the exogenous target bar gene and the internal reference lectin gene (Qiu et al., 2012). The $20 \mu \mathrm{l}$ qRT-PCR reaction mixture contained the following components: $1 \mu \mathrm{l}(100 \mathrm{ng})$ template DNA, $10 \mu \mathrm{l} 2 \times \mathrm{SYBR}^{\circledR}$ Premix Taq ${ }^{\mathrm{TM}}, 0.4 \mu \mathrm{l}(20 \mu \mathrm{M})$ of the forward and reverse primers 
(Table S2), and $8.2 \mu \mathrm{l}$ of sterile $\mathrm{ddH}_{2} \mathrm{O}$. The PCR condition was set as one cycle at $95^{\circ} \mathrm{C}$ for $3 \mathrm{~min}$, followed by 40 cycles of $95^{\circ} \mathrm{C}$ for $10 \mathrm{~s}, 55^{\circ} \mathrm{C}$ for $15 \mathrm{~s}$, and $72^{\circ} \mathrm{C}$ for $15 \mathrm{~s}$. Each sample was repeated three times.

\section{Determination of Agrobacterium Infection Efficiency, Rate of Shoot Elongation and transformation Efficiency}

The Agrobacterium infection efficiency was estimated by the rate of GUS transient expression in soybean cotyledonary explants. The rate of GUS transient expression $(\%)=$ (The number of cotyledonary explants in blue color/total number of cotyledonary explants for staining) $\times 100 \%$. The rate of shoot elongation $(\%)$ $=$ (The number of elongated shoots with heights $\geq 3 \mathrm{~cm} /$ the number of infected explants) $\times 100 \%$. The transformation efficiency $(\%)=$ (The number of positive transgenic plants / the number of infected explants) $\times 100 \%$.

\section{Statistical Analysis}

SAS 9.2 software was used for statistical analysis. Differences between two groups were analyzed by student's $t$-test, while differences among multiple treatments were analyzed using Duncan's multiple range test. GraphPad Prism, Microsoft Excel, and PowerPoint were used to generate graphs.

\section{RESULTS}

\section{The Effect of DTT on the Transient GUS Expression in Soybean Explants}

The rate of GUS transient expression in the cotyledonary explants reflects the infection efficiency of Agrobacterium. In order to see the effect of the antioxidant DTT on the transient GUS expression in explants, 0 or $154.2 \mathrm{mg} / \mathrm{L}$ DTT was added to the resuspended infection medium after collecting the Agrobacterium when $\mathrm{OD}_{650}=0.6$. The half-seed explants from 1-d imbibition were infected by the Agrobacterium suspension medium with or without DTT, and subjected to GUS staining after 5 days of co-cultivation. According to the GUS staining intensity, the explants were divided into three categories: strong, weak, and none (Figure 3). The rate of total transient GUS expression in the cotyledonary explants after adding DTT in re-suspended infection medium was increased by 13 and 3\% for Jack Purple and Tianlong 1, respectively (Figures 4A,B), compared with the control (without DTT), and the rate of strong GUS transient expression was significantly $(P<0.05$, student's $t$-test) increased by 16 and $35 \%$ for Jack Purple and Tianlong 1, respectively (Figures 4C,D).

\section{The Effect of Agrobacterium Concentration on the Transient GUS Expression in Explants}

To determine the optimal concentration of Agrobacterium for infection, the Agrobacterium at three different $\mathrm{OD}_{650}(0.6,0.8$, 1.0) during logarithmic growth stage (Figure S1) were collected, respectively, and re-suspended in the liquid CCM containing $154.2 \mathrm{mg} / \mathrm{L}$ DTT, then co-cultured with soybean half-seed explants (from 1-d imbibition) for 5 days. The explants were stained after 5 days of co-cultivation.

The rate of total GUS transient expression in the cotyledonary explants of both soybean varieties (Jack Purple and Tianlong 1) was not significantly different among the concentrations of $\mathrm{OD}_{650}=0.6,0.8$, and 1.0 (Figures 5A,B). However, for both soybean varieties, the rate of strong GUS transient expression was significantly ( $P<0.05$, Duncan's multiple range test) higher when using the concentration of $\mathrm{OD}_{650}=0.6$ than $\mathrm{OD}_{650}=1$, and slightly higher than $\mathrm{OD}_{650}=0.8$ (Figures 5C,D). Therefore, we conclude that the optimal concentration of Agrobacterium for infection is $\mathrm{OD}_{650}=0.6$.

\section{The Effect of Different Explants on the Transient GUS Expression}

The Agrobacterium infection efficiencies were then compared among four different explants prepared by 1-d imbibition, 1-d germination, 3-d germination, and 5-d germination, respectively, using two soybean varieties of Jack Purple and Tianlong 1 . The Agrobacterium was collected at $\mathrm{OD}_{650}=0.6$, and re-suspended in the liquid CCM containing $154.2 \mathrm{mg} / \mathrm{L}$ DTT to infect above four different explants, respectively. After 5 days of co-cultivation, the explants were subjected to GUS staining. The result showed that the highest rate of total GUS transient expression in the cotyledonary explants was achieved when using the half-seed explants from 1-d imbibition for both soybean varieties, 95 and

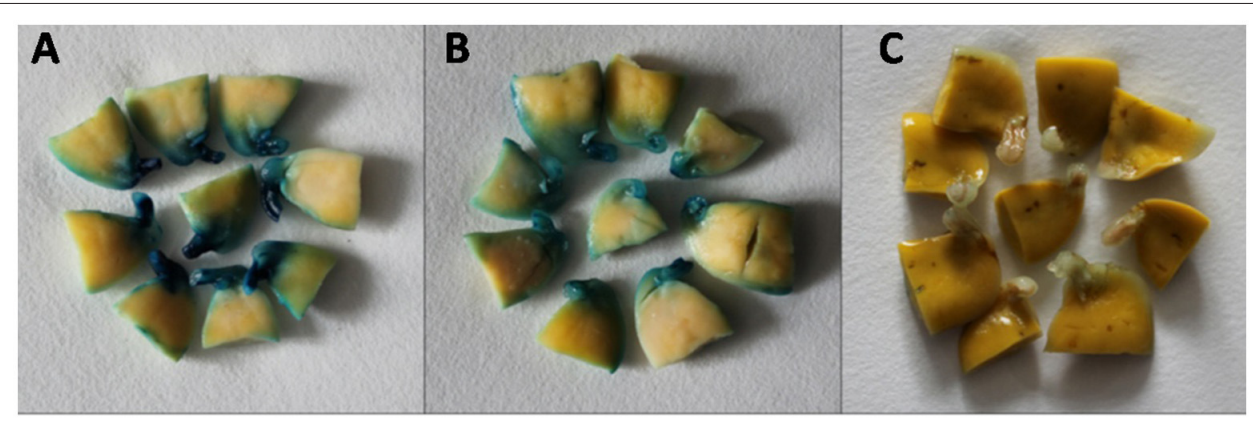

FIGURE 3 | Classification standards of GUS staining. (A) Strong, with deep dyeing in the cotyledonary explants. (B) Weak, with light dyeing in the cotyledonary explants. (C) None, with no dyeing in the cotyledonary explants. 

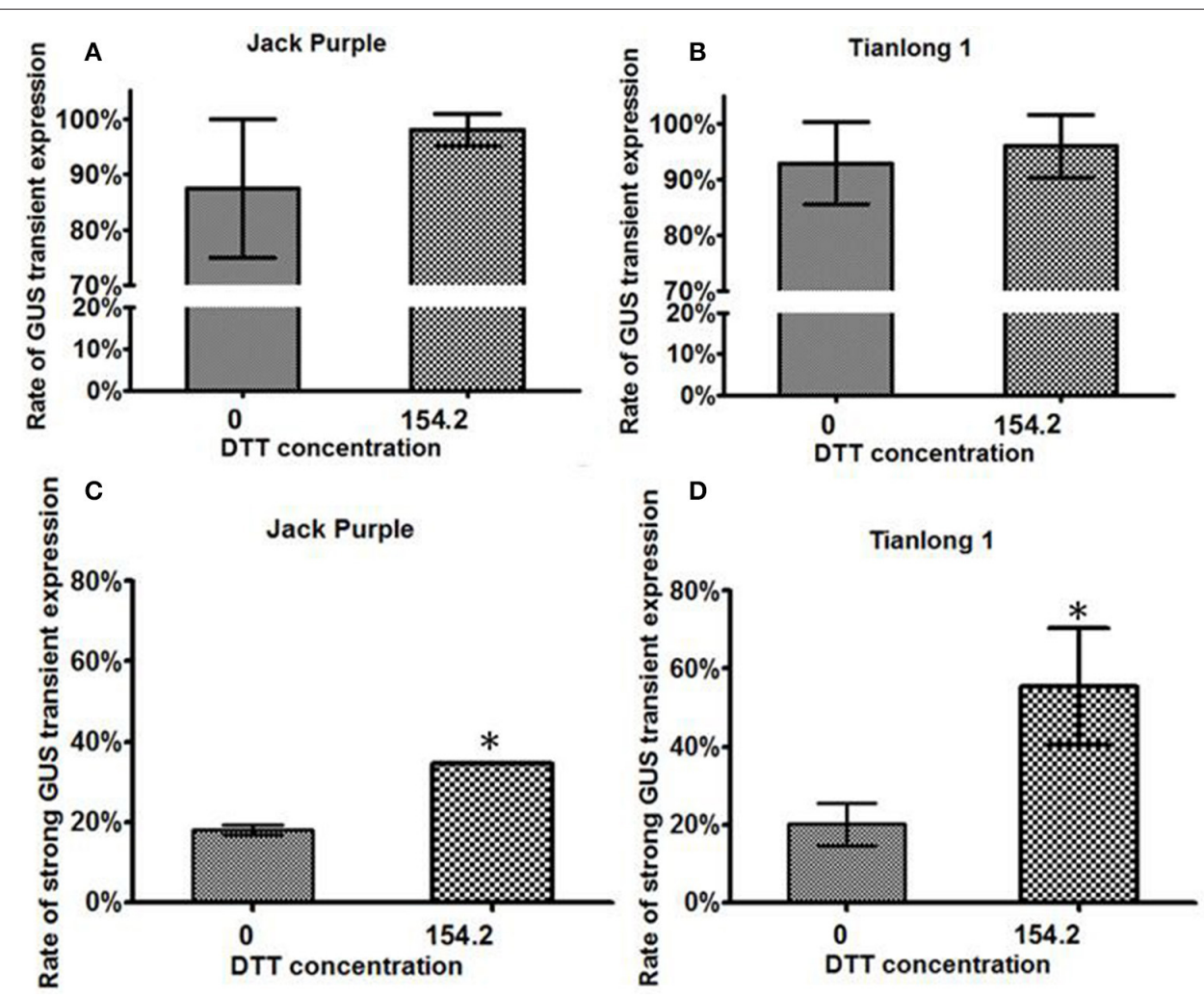

FIGURE 4 | The effect of DTT on the transient GUS expression in soybean cotyledonary explants. (A) Rate of total GUS transient expression in Jack Purple explants. (B) Rate of total GUS transient expression in Tianlong 1 explants. (C) Rate of strong GUS transient expression in Jack Purple explants. (D) Rate of strong GUS transient expression in Tianlong 1 explants. Results are expressed as mean \pm standard error. Fifty explants were stained for each treatment and the experiments were repeated twice. * above bars indicates significant difference between 0 and $154.2 \mathrm{mg} / \mathrm{L}$ DTT at 0.05 level by student's $t$-test. Rate of total GUS transient expression $(\%)=($ The number of explants with deep and weak dyeing $/$ Total number of explants for staining $) \times 100 \%$. Rate of strong GUS transient expression (\%) $=$ (The number of explants with deep dyeing/Total number of explants for staining) $\times 100 \%$.

97\% in Jack Purple and Tianlong 1, respectively, which was significantly $(P<0.05$, Duncan's multiple range test) higher than the other three types of explants (Figure 6).

\section{The Effect of Co-Cultivation Time on Transient GUS Expression in Soybean Explants}

The Agrobacterium was collected at $\mathrm{OD}_{650}=0.6$, and resuspended in the liquid CCM containing $154.2 \mathrm{mg} / \mathrm{L} \mathrm{DTT}$ to infect the soybean half-seed explants from 1-d imbibition. After $3,4,5$, or 6 days of co-cultivation, the explants were subjected to GUS staining. The results showed that the transient GUS expression rates after four different co-cultivation time were not significantly different (Figure 7). However, the explants were almost yellow when co-cultivated for 3 or 4 days but turned green after 5 days (Figure S2). Therefore, 5 - $\mathrm{d}$ co-cultivation is chosen when the explants have a strong vitality.

\section{Rate of Transient GUS Expression in Different Soybean Varieties}

Eight soybean varieties, including Tianlong 1, Jack Purple, DLH, NN419, Williams 82, HZM, NN34, and NN88-1, were used to compare the soybean genotype effect on the Agrobacterium infection efficiency, with all the other factors optimized (which was collecting the Agrobacterium when $\mathrm{OD}_{650}=0.6$, then resuspended in the liquid CCM with $154.2 \mathrm{mg} / \mathrm{L}$ DTT to infect the half-seed explants from 1-d imbibition, and co-cultured for 5 days). The results showed that the rate of transient GUS expression in Tianlong 1 and Jack Purple was significantly $(P<$ 0.05, Duncan's multiple range test) higher than in HZM, NN34, and NN88-1 (Figure 8). We chose Tianlong 1 and Jack Purple in further experiments because of their higher rate of transient GUS expression.

\section{The Effect of Different Concentration Combinations of $\mathrm{GA}_{3}$ and IAA on the Rate of Shoot Elongation and Transformation Efficiency in Soybean}

$\mathrm{GA}_{3}$ and IAA are important phytohormones to regulate plant growth. $\mathrm{GA}_{3}$ promotes stem elongation while IAA mainly promotes cell elongation (Ji and Yang, 2002). Optimum phytohormone concentration is a key factor to improve the regeneration efficiency and transformation efficiency of plants. Based on the original concentration of $\mathrm{GA}_{3}$ and IAA $(0.5 \mathrm{mg} / \mathrm{L}$ 

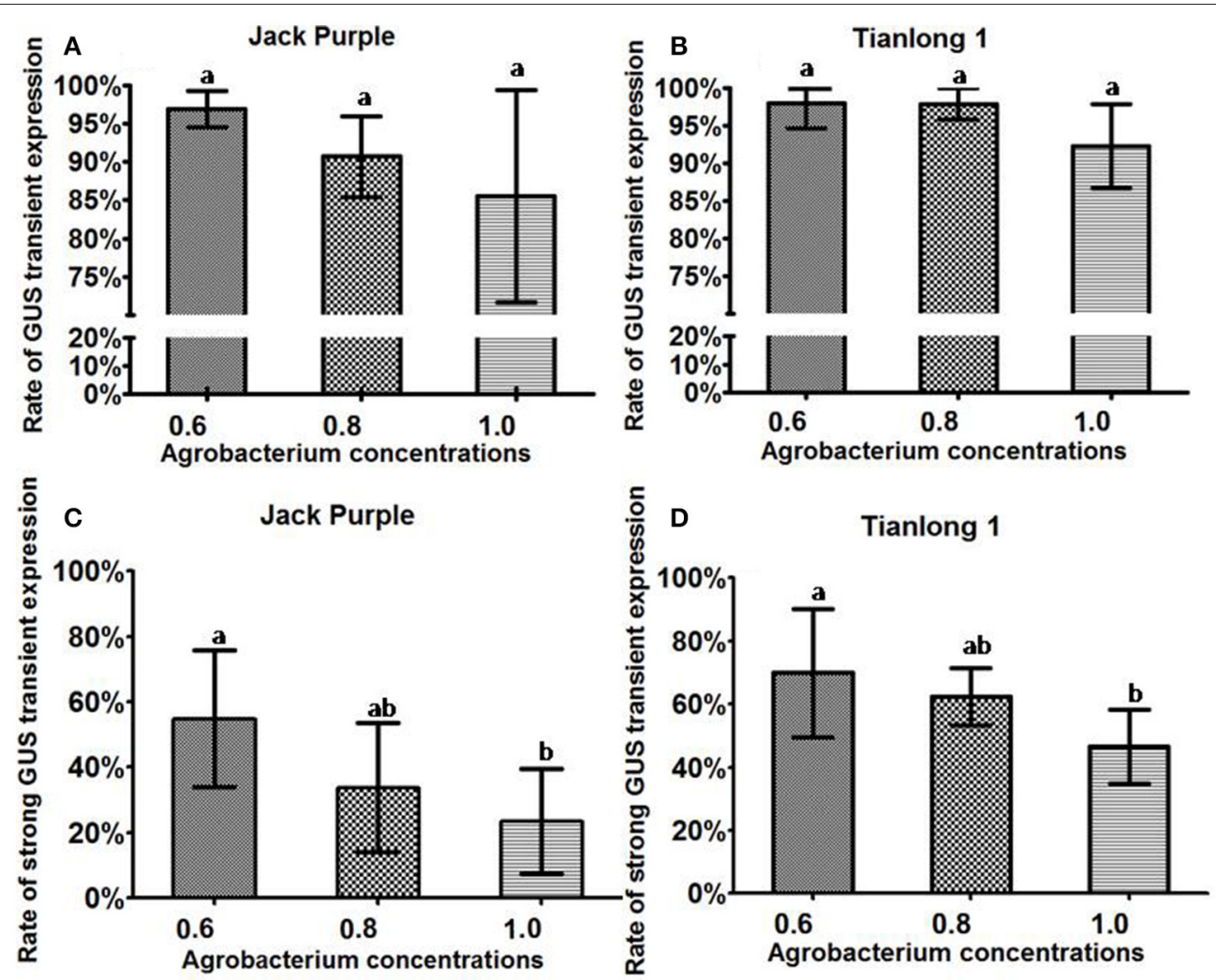

FIGURE 5 | The effect of Agrobacterium concentration on the transient GUS expression in soybean cotyledonary explants. (A) Rate of total GUS transient expression in the cotyledonary explants of Jack Purple. (B) Rate of total GUS transient expression in the cotyledonary explants of Tianlong 1. (C) Rate of strong GUS transient expression in the cotyledonary explants of Jack Purple. (D) Rate of strong GUS transient expression in the cotyledonary explants of Tianlong 1. Results are expressed as mean \pm standard error. Fifty explants were stained for each treatment and the experiments were repeated five times. Means with the same letter above bars are not significantly different at 0.05 level according to Duncan's multiple range test. Rate of total GUS transient expression (\%) $=$ (The number of explants with deep and weak dyeing/Total number of explants for staining) $\times 100 \%$. Rate of strong GUS transient expression $(\%)=($ The number of explants with deep dyeing/Total number of explants for staining) $\times 100 \%$.

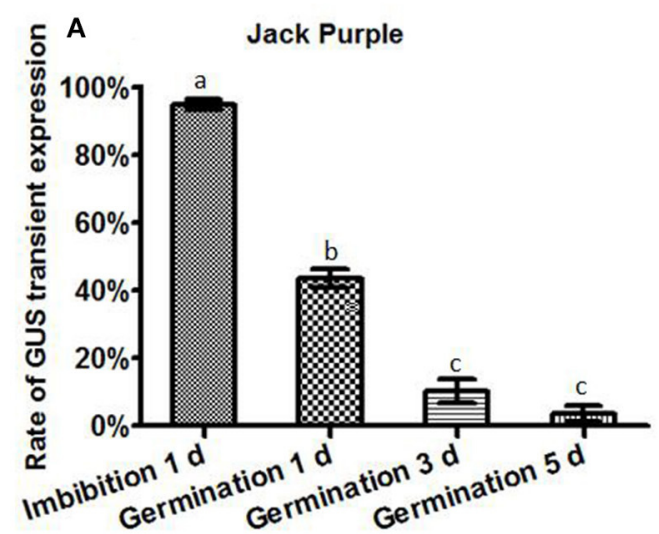

Explants

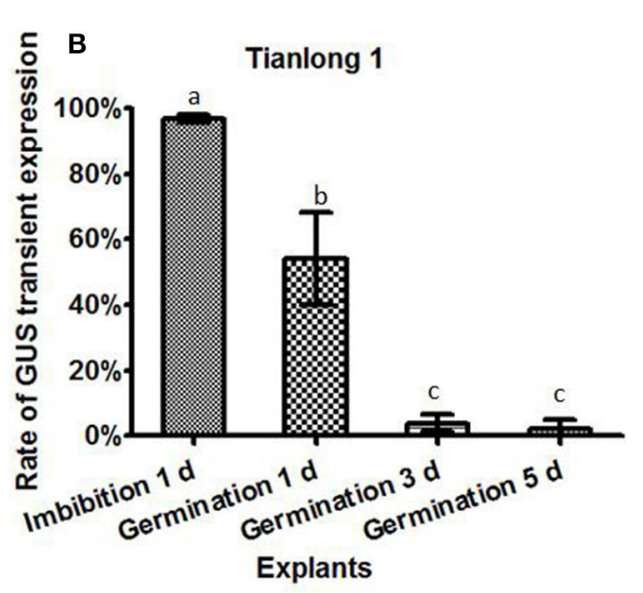

FIGURE 6 | The effect of different explants on the transient GUS expression. The cotyledonary explants were obtained by four different methods, including imbibition for $1 \mathrm{~d}$, germination for 1, 3, and $5 \mathrm{~d}$. (A) Rate of total GUS transient expression in the cotyledonary explants of Jack Purple. (B) Rate of total GUS transient expression in the cotyledonary explants of Tianlong 1. The results are expressed as mean \pm standard error. Fifty explants were stained for each treatment and the experiments were repeated twice. Means with the same letter above bars are not significantly different at 0.05 level according to Duncan's multiple range test. Rate of total GUS transient expression $(\%)=($ The number of explants with deep and weak dyeing/Total number of explants for staining) $\times 100 \%$. 

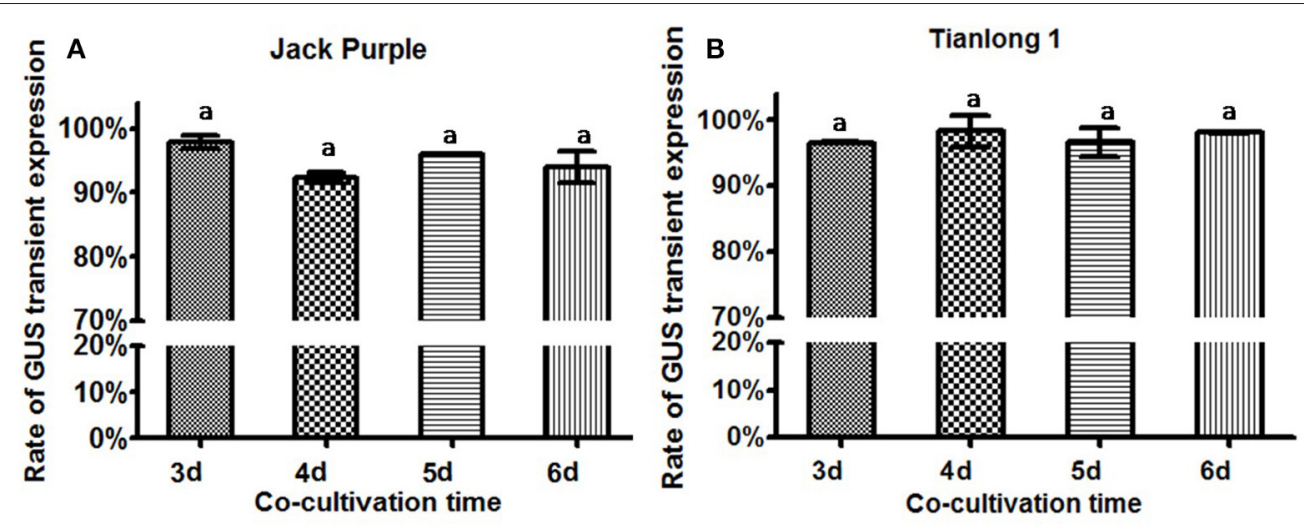

FIGURE 7 | The effect of co-cultivation time on transient GUS expression in soybean explants. (A) Rate of total GUS transient expression in the cotyledonary explants of Jack Purple. (B) Rate of total GUS transient expression in the cotyledonary explants of Tianlong 1. Results are expressed as mean \pm standard error. Fifty explants were stained for each treatment and the experiments were repeated twice. Means with the same letter above bars are not significantly different at 0.05 level according to Duncan's multiple range test. Rate of total GUS transient expression (\%) = (The number of explants with deep and weak dyeing/Total number of explants for staining) $\times 100 \%$.

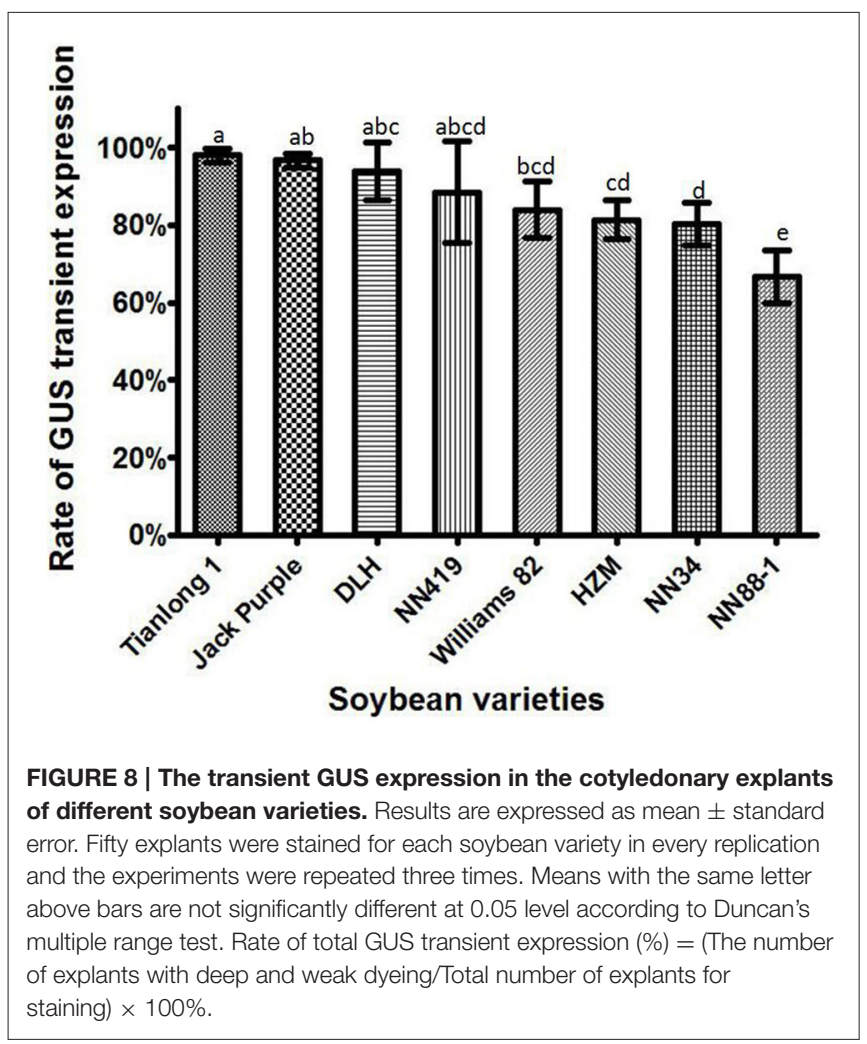

$\mathrm{GA}_{3}$ and $0.1 \mathrm{mg} / \mathrm{L}$ IAA) in SEM (Paz et al., 2006), we used three levels of $\mathrm{GA}_{3}$ concentration $(0.5,1.0$, and $1.5 \mathrm{mg} / \mathrm{L})$ and two levels of IAA concentration $(0.1$ and $0.2 \mathrm{mg} / \mathrm{L})$ in the experimental design, which would be six combinations (Table 1). The rate of shoot elongation and transformation efficiency in Jack Purple and Tianlong 1 were calculated respectively (Table 1). The results showed that the highest rate of shoot elongation in Jack Purple was $33.54 \%$ when $1.0 \mathrm{mg} / \mathrm{L} \mathrm{GA}_{3}$ and $0.1 \mathrm{mg} / \mathrm{L} \mathrm{IAA}$
TABLE 1 | The effect of combination of different $\mathrm{GA}_{3}$ and IAA concentrations on the rate of shoot elongation and transformation efficiency in soybean.

\begin{tabular}{|c|c|c|c|c|}
\hline $\begin{array}{l}\text { Soybean } \\
\text { variety }\end{array}$ & $\begin{array}{c}\mathrm{GA}_{3} \\
\text { concentration } \\
(\mathrm{mg} / \mathrm{L})\end{array}$ & $\begin{array}{c}\text { IAA } \\
\text { concentration } \\
(\mathrm{mg} / \mathrm{L})\end{array}$ & $\begin{array}{c}\text { Rate of } \\
\text { shoot } \\
\text { elongation (\%) }\end{array}$ & $\begin{array}{l}\text { Transformation } \\
\text { efficiency (\%) }\end{array}$ \\
\hline \multirow[t]{6}{*}{ Jack Purple } & 0.5 & 0.1 & $16.11 \pm 0.05^{b}$ & $5.00 \pm 0.03^{a}$ \\
\hline & 0.5 & 0.2 & $13.70 \pm 0.02^{b}$ & $4.57 \pm 0.01^{a}$ \\
\hline & 1.0 & 0.1 & $33.54 \pm 0.03^{a}$ & $7.32 \pm 0.01^{a}$ \\
\hline & 1.0 & 0.2 & $17.42 \pm 0.01^{b}$ & $5.26 \pm 0.01^{a}$ \\
\hline & 1.5 & 0.1 & $11.49 \pm 0.01^{b}$ & $5.41 \pm 0.03^{\mathrm{a}}$ \\
\hline & 1.5 & 0.2 & $13.39 \pm 0.05^{b}$ & $5.36 \pm 0.01^{a}$ \\
\hline \multirow[t]{6}{*}{ Tianlong 1} & 0.5 & 0.1 & $14.75 \pm 0.01^{a b}$ & $4.28 \pm 0.00^{a}$ \\
\hline & 0.5 & 0.2 & $10.60 \pm 0.01^{b}$ & $1.76 \pm 0.02^{\mathrm{a}}$ \\
\hline & 1.0 & 0.1 & $26.08 \pm 0.07^{a}$ & $10.01 \pm 0.03^{a}$ \\
\hline & 1.0 & 0.2 & $9.80 \pm 0.04^{b}$ & $3.53 \pm 0.02^{\mathrm{a}}$ \\
\hline & 1.5 & 0.1 & $19.56 \pm 0.05^{a b}$ & $4.49 \pm 0.03^{a}$ \\
\hline & 1.5 & 0.2 & $14.40 \pm 0.03^{a b}$ & $5.69 \pm 0.04^{a}$ \\
\hline
\end{tabular}

The results are expressed as mean \pm standard error. Eighty explants were infected by Agrobacterium for each combination/treatment and the experiments were repeated twice. The concentrations of glufosinate for selection were $5 \mathrm{mg} / \mathrm{L}$ and $3 \mathrm{mg} / \mathrm{L}$ in SIM and SEM, respectively. The numbers of elongated shoots (height $\geq 3 \mathrm{~cm}$ ) were recorded during SEM stage. For each soybean variety, means with the same letter are not significantly different at 0.05 level according to Duncan's multiple range test. Rate of shoot elongation $(\%)=$ (The number of elongated shoots/the number of infected explants) $\times 100 \%$. Transformation efficiency $(\%)=($ The number of the positive plants/the number of infected explants) $\times 100 \%$.

were added in SEM, which was significantly $(P<0.05$, Duncan's multiple range test) higher than the original concentration combination of $\mathrm{GA}_{3}$ and IAA $(0.5 \mathrm{mg} / \mathrm{L} \mathrm{GA} 3$ and $0.1 \mathrm{mg} / \mathrm{L}$ IAA) in SEM (Table 1, Figure 9). Similar results were found for Tianlong 1 . The highest rate of shoot elongation in Tianlong 1 was $26.08 \%$ when $1.0 \mathrm{mg} / \mathrm{L} \mathrm{GA}_{3}$ and $0.1 \mathrm{mg} / \mathrm{L}$ IAA were added in SEM (Table 1). The transformation efficiencies in Jack Purple 


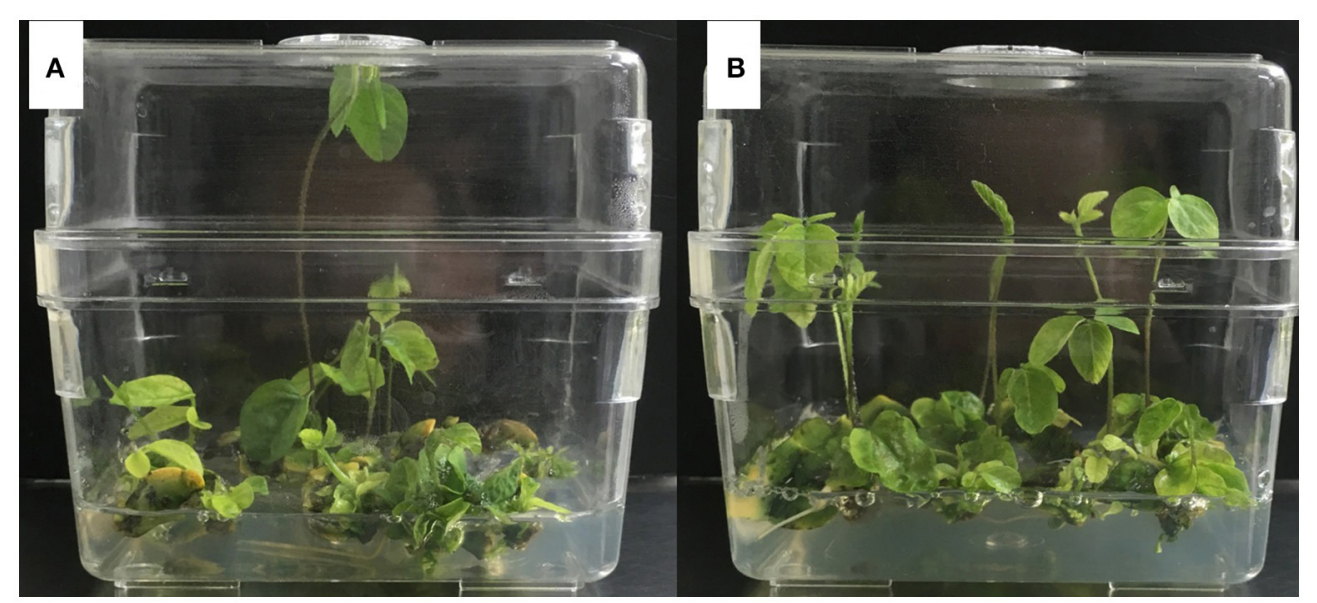

FIGURE 9 | The explants of soybean variety Jack Purple in the shoot elongation medium. (A) Soybean explants on SEM with $0.5 \mathrm{mg} / \mathrm{L} \mathrm{GA}$ and $0.1 \mathrm{mg} / \mathrm{L}$ IAA. (B) Soybean explants on SEM with $1.0 \mathrm{mg} / \mathrm{L} \mathrm{GA}_{3}$ and $0.1 \mathrm{mg} / \mathrm{L} \mathrm{IAA}$.

and Tianlong 1 were 7.32 and $10.01 \%$ when SEM contained $1.0 \mathrm{mg} / \mathrm{L} \mathrm{GA}_{3}$ and $0.1 \mathrm{mg} / \mathrm{L}$ IAA, which were higher than 5.00 and $4.28 \%$ when SEM contained $0.5 \mathrm{mg} / \mathrm{L} \mathrm{GA}_{3}$ and $0.1 \mathrm{mg} / \mathrm{L}$ IAA, respectively (Table 1). These results suggest that the optimal concentration combination of $\mathrm{GA}_{3}$ and IAA $(1.0 \mathrm{mg} / \mathrm{L} \mathrm{GA}$ and $0.1 \mathrm{mg} / \mathrm{L}$ IAA) improved the rate of shoot elongation and transformation efficiency in soybean varieties of Jack Purple and Tianlong 1.

\section{The Effect of $\mathrm{AgNO}_{3}$ and $\mathrm{Vc}$ on the Rate of Shoot Elongation and Transformation Efficiency in Soybean}

Tissue browning is another factor affecting transformation efficiency. 88-1 is one of the soybean varieties that encountered more serious tissue browning. Therefore, we added $\mathrm{AgNO}_{3}$ $\left(5,10\right.$, or $15 \mathrm{mg} / \mathrm{L}$ ) to SIM and SEM (with $0.5 \mathrm{mg} / \mathrm{L} \mathrm{GA}_{3}$ and $0.1 \mathrm{mg} / \mathrm{L}$ IAA in SEM) during tissue culturing 88-1 explants. We did not observe alleviation of the tissue browning after adding $\mathrm{AgNO}_{3}$. However, the shoot elongation rate increased after adding different concentrations of $\mathrm{AgNO}_{3}$, and the transformation efficiency in 88-1 improved from 3.17 to $5.50 \%$ after adding $15 \mathrm{mg} / \mathrm{L} \mathrm{AgNO}_{3}$ (Table S3).

Therefore, we further investigated the effect of adding $15 \mathrm{mg} / \mathrm{L}$ $\mathrm{AgNO}_{3}$ in SIM and SEM (with $0.1 \mathrm{mg} / \mathrm{L}$ IAA in SEM) using the other two soybean varieties of Jack Purple and Tianlong 1. Because doubling $\mathrm{GA}_{3}$ concentration in SEM improved the rate of shoot elongation (Table 1), we investigated the effect of $\mathrm{AgNO}_{3}$ under two levels of $\mathrm{GA}_{3}$ concentration in SEM. In Jack Purple, the results showed that the rate of shoot elongation and transformation efficiency decreased when adding $15 \mathrm{mg} / \mathrm{L} \mathrm{AgNO}_{3}$ in SIM and SEM (Table 2), and abnormal leaves were observed on Jack Purple after adding $15 \mathrm{mg} / \mathrm{L}$ $\mathrm{AgNO}_{3}$ in the medium (Figure S3). In Tianlong 1, the rate of shoot elongation increased from 14.75 to $19.47 \%$ at the level of $0.5 \mathrm{mg} / \mathrm{L} \mathrm{GA}_{3}$ and from 26.08 to $31.82 \%$ at the level of $1.0 \mathrm{mg} / \mathrm{L} \mathrm{GA}$. However, adding $15 \mathrm{mg} / \mathrm{L} \mathrm{AgNO}_{3}$ in SIM
TABLE 2 | The effect of $\mathrm{AgNO}_{3}$ on the rate of shoot elongation and transformation efficiency in soybean.

\begin{tabular}{lcccc}
\hline $\begin{array}{l}\text { Soybean } \\
\text { variety }\end{array}$ & $\begin{array}{c}\mathbf{G A}_{\mathbf{3}} \\
\text { concentration } \\
(\mathbf{m g} / \mathbf{L})\end{array}$ & $\begin{array}{c}\mathbf{A g N O}_{\mathbf{3}} \\
\text { concentration } \\
(\mathbf{m g} / \mathbf{L})\end{array}$ & $\begin{array}{c}\text { Rate of } \\
\text { shoot } \\
\text { elongation (\%) }\end{array}$ & $\begin{array}{c}\text { Transformation } \\
\text { efficiency (\%) }\end{array}$ \\
\hline Jack Purple & 0.5 & 0 & $16.11 \pm 0.05^{\mathrm{b}}$ & $5.00 \pm 0.03^{\mathrm{a}}$ \\
& 0.5 & 15 & $14.44 \pm 0.00^{\mathrm{b}}$ & $3.89 \pm 0.02^{\mathrm{a}}$ \\
& 1 & 0 & $33.54 \pm 0.03^{\mathrm{a}}$ & $7.32 \pm 0.01^{\mathrm{a}}$ \\
& 1 & 15 & $26.22 \pm 0.02^{\mathrm{ab}}$ & $6.71 \pm 0.01^{\mathrm{a}}$ \\
\hline Tianlong 1 & 0.5 & 0 & $14.75 \pm 0.01^{\mathrm{a}}$ & $4.28 \pm 0.00^{\mathrm{a}}$ \\
& 0.5 & 15 & $19.47 \pm 0.03^{\mathrm{a}}$ & $5.44 \pm 0.03^{\mathrm{a}}$ \\
& 1 & 0 & $26.08 \pm 0.07^{\mathrm{a}}$ & $10.01 \pm 0.03^{\mathrm{a}}$ \\
& 1 & 15 & $31.82 \pm 0.00^{\mathrm{a}}$ & $9.09 \pm 0.01^{\mathrm{a}}$ \\
\hline
\end{tabular}

The results are expressed as mean \pm standard error. Eighty explants were infected by Agrobacterium for each combination/treatment and the experiments were repeated twice. The concentrations of glufosinate for selection were $5 \mathrm{mg} / \mathrm{L}$ and $3 \mathrm{mg} / \mathrm{L}$ in SIM and SEM, respectively. The numbers of elongated shoots (height $\geq 3 \mathrm{~cm}$ ) were recorded during SEM stage. For each soybean variety, means with the same letter are not significantly different at 0.05 level according to Duncan's multiple range test. Rate of shoot elongation $(\%)=$ (The number of elongated shoots/the number of infected explants) $\times 100 \%$. Transformation efficiency $(\%)=$ (The number of the positive plants $/$ the number of infected explants) $\times 100 \%$.

and SEM had little effect on the transformation efficiency (Table 2).

Previous studies showed that adding $200 \mathrm{mg} / \mathrm{L} \mathrm{Vc}$ in the medium can prevent tissue browning in Bromeliaceae (Peng et al., 2007) and promote rooting in Limonium (Xu et al., 2010). Therefore, we added $200 \mathrm{mg} / \mathrm{L} \mathrm{Vc}$ to SIM and SEM (with $0.1 \mathrm{mg} / \mathrm{L}$ IAA in SEM) to see if $\mathrm{Vc}$ can prevent browning and improve the rate of shoot elongation and transformation efficiency in Jack Purple and Tianlong 1. For Jack Purple, the rate of shoot elongation increased from 16.11 to $23.17 \%$, and the transformation efficiency increased from 5.00 to $9.15 \%$ after adding $200 \mathrm{mg} / \mathrm{L} \mathrm{Vc}$ in SIM and SEM when $\mathrm{GA}_{3}$ concentration 
was $0.5 \mathrm{mg} / \mathrm{L}$ in SEM. When the $\mathrm{GA}_{3}$ concentration was 1 $\mathrm{mg} / \mathrm{L}$ in SEM, the rate of shoot elongation was reduced but the transformation efficiency increased slightly (Table 3). For Tianlong 1, the rate of shoot elongation and transformation efficiency was slightly improved after adding $200 \mathrm{mg} / \mathrm{L} \mathrm{Vc}$ in SIM and SEM when $\mathrm{GA}_{3}$ concentration was $0.5 \mathrm{mg} / \mathrm{L}$ in SEM. However, at $1 \mathrm{mg} / \mathrm{L} \mathrm{GA}_{3}$ in SEM, the rate of shoot elongation and transformation efficiency decreased after adding $200 \mathrm{mg} / \mathrm{L} \mathrm{Vc}$ in SIM and SEM. These results suggested that the tissue culture medium should be optimized specifically for different soybean varieties.

\section{Confirmation of Positive Transgenic Soybean Plants}

The positive $T_{0}$ transgenic soybean plants were first identified by GUS staining of young leaves during rooting stage. A total of 20 positive transgenic plants were randomly picked for further confirmation using the other four different methods, including GUS staining after transplanting, PCR amplification of exogenous gene, herbicide (glufosinate) painting, and LibertyLink $^{\circledR}$ strip detection. The results (Table 4) showed that all methods were consistent except that GUS staining after transplanting missed four positive transgenic plants. Therefore, GUS staining during rooting stage is recommended first since this method can identify positive transgenic plants as soon as possible, and herbicide painting would be an easy and reliable method to confirm the results.

The positive $T_{1}$ transgenic soybean plants were also confirmed by four different methods (Figure 10). The copy number of bar gene was analyzed by absolute quantitative PCR using lectin as the reference gene (Qiu et al., 2012). The melting curves of bar and lectin genes showed specific amplification (Figure S4). The

TABLE 3 | The effect of Vc on the rate of shoot elongation and transformation efficiency in soybean.

\begin{tabular}{|c|c|c|c|c|}
\hline $\begin{array}{l}\text { Soybean } \\
\text { variety }\end{array}$ & $\begin{array}{c}\mathrm{GA}_{3} \\
\text { concentration } \\
(\mathrm{mg} / \mathrm{L})\end{array}$ & $\begin{array}{c}\text { Vc } \\
\text { concentration } \\
(\mathrm{mg} / \mathrm{L})\end{array}$ & $\begin{array}{c}\text { Rate of } \\
\text { shoot } \\
\text { elongation (\%) }\end{array}$ & $\begin{array}{l}\text { Transformation } \\
\text { efficiency (\%) }\end{array}$ \\
\hline \multirow[t]{4}{*}{ Jack Purple } & 0.5 & 0 & $16.11 \pm 0.05^{b}$ & $5.00 \pm 0.03^{a}$ \\
\hline & 0.5 & 200 & $23.17 \pm 0.04^{a b}$ & $9.15 \pm 0.02^{\mathrm{a}}$ \\
\hline & 1 & 0 & $33.54 \pm 0.03^{a}$ & $7.32 \pm 0.01^{a}$ \\
\hline & 1 & 200 & $28.05 \pm 0.04^{a b}$ & $8.54 \pm 0.02^{a}$ \\
\hline \multirow[t]{4}{*}{ Tianlong 1} & 0.5 & 0 & $14.75 \pm 0.01^{a}$ & $4.28 \pm 0.00^{\mathrm{a}}$ \\
\hline & 0.5 & 200 & $17.73 \pm 0.02^{a}$ & $4.55 \pm 0.00^{\mathrm{a}}$ \\
\hline & 1 & 0 & $26.08 \pm 0.07^{a}$ & $10.01 \pm 0.03^{a}$ \\
\hline & 1 & 200 & $19.09 \pm 0.02^{a}$ & $4.55 \pm 0.01^{a}$ \\
\hline
\end{tabular}

The results are expressed as mean \pm standard error. Eighty explants were infected by Agrobacterium for each combination/treatment and the experiments were repeated twice. The concentrations of glufosinate for selection were $5 \mathrm{mg} / \mathrm{L}$ and $3 \mathrm{mg} / \mathrm{L}$ in SIM and SEM, respectively. The numbers of elongated shoots (height $\geq 3 \mathrm{~cm}$ ) were recorded during SEM stage. For each soybean variety, means with the same letter are not significantly different at 0.05 level according to Duncan's multiple range test. Rate of shoot elongation $(\%)=$ (The number of elongated shoots/the number of infected explants) $\times 100 \%$. Transformation efficiency (\%) $=$ (The number of the positive plants/the number of infected explants) $\times 100 \%$. equation for the standard curve of the endogenous reference gene lectin in Jack Purple and Tianlong 1 was $y=-3.483 \mathrm{x}+$ $35.33\left(R^{2}=0.995\right)$, and $y=-3.167 \mathrm{x}+36.49\left(R^{2}=0.986\right)$, respectively; while the equation for the standard curve of bar gene in plasmid was $y=-3.116 \mathrm{x}+40.78\left(R^{2}=0.984\right)$. Then the ratio of exogenous gene (bar) and reference gene (lectin) was calculated. Because lectin is a single gene in soybean genome (Vodkin et al., 1983), so the ratio of exogenous gene (bar) and reference gene (lectin) represents the copy of the exogenous gene (bar). The results showed that transgenic soybean line 3 and line 6 had one copy, line 2, and line 4 had two copies, line 1 and line 5 had three copies of bar gene (Table 5).

\section{DISCUSSION}

Since the cotyledonary nodes were used as explants to obtain the first transgenic soybean plant by Agrobacterium-mediated transformation (Hinchee et al., 1988), this method has been modified and an improved transformation efficiency of $3.8 \%$ (on average) was achieved (Paz et al., 2006). However, this efficiency is still low to sufficiently screen enough transformation events for molecular breeding or gene function studies. Therefore, we try to further improve the transformation efficiency by increase the Agrobacterium infection efficiency and the rate of shoot elongation in soybean.

When the Agrobacterium concentration is too high to infect the explants, it is hard to wash the Agrobacterium away from the explants and will lead to Agrobacterium contamination. But if the concentration of Agrobacterium is too low, the infection ability is weak (Zhong, 2007). Therefore, it is better to choose a relatively low concentration with high infection ability. In this study, we found that $\mathrm{OD}_{650}=0.6$ is the optimum concentration for infection. In addition, other factors affecting Agrobacterium infection efficiency were also investigated by estimation of the rate of GUS transient expression in soybean cotyledonary explants, including soybean explants, Agrobacterium suspension medium, and co-cultivation time. An infection efficiency of over $96 \%$ was achieved by collecting the Agrobacterium at a concentration of $\mathrm{OD}_{650}=0.6$, then re-suspended in liquid CCM containing $154.2 \mathrm{mg} / \mathrm{L}$ DTT to infect the half-seed cotyledonary explants (from mature seeds imbibed for 1 day), and co-cultured them for 5 days. Among the eight soybean varieties, higher Agrobacterium infection efficiencies were observed for soybean varieties Tianlong 1, Jack Purple, DLH, and NN419 (Figure 8).

TABLE 4 | Comparison of different methods to detect positive transgenic soybean plants at $T_{0}$ generation.

\begin{tabular}{lcll}
\hline Method & $\begin{array}{l}\text { Number of positive } \\
\text { plants/Total plants }\end{array}$ & $\begin{array}{l}\text { Time after } \\
\text { shoot } \\
\text { elongation }\end{array}$ & $\begin{array}{l}\text { Time } \\
\text { needed } \\
\text { for testing }\end{array}$ \\
\hline GUS staining during rooting & $20 / 20$ & 1 day & Overnight \\
GUS staining after transplanting & $16 / 20$ & 2 weeks & Overnight \\
PCR amplification of GUS gene & $20 / 20$ & $3-4$ weeks & 2 h \\
Glufosinate painting on leaves & $20 / 20$ & 4 weeks & 7 days \\
LibertyLink ${ }^{\circledR}$ strip detection & $20 / 20$ & 4 weeks & 10 min \\
\hline
\end{tabular}




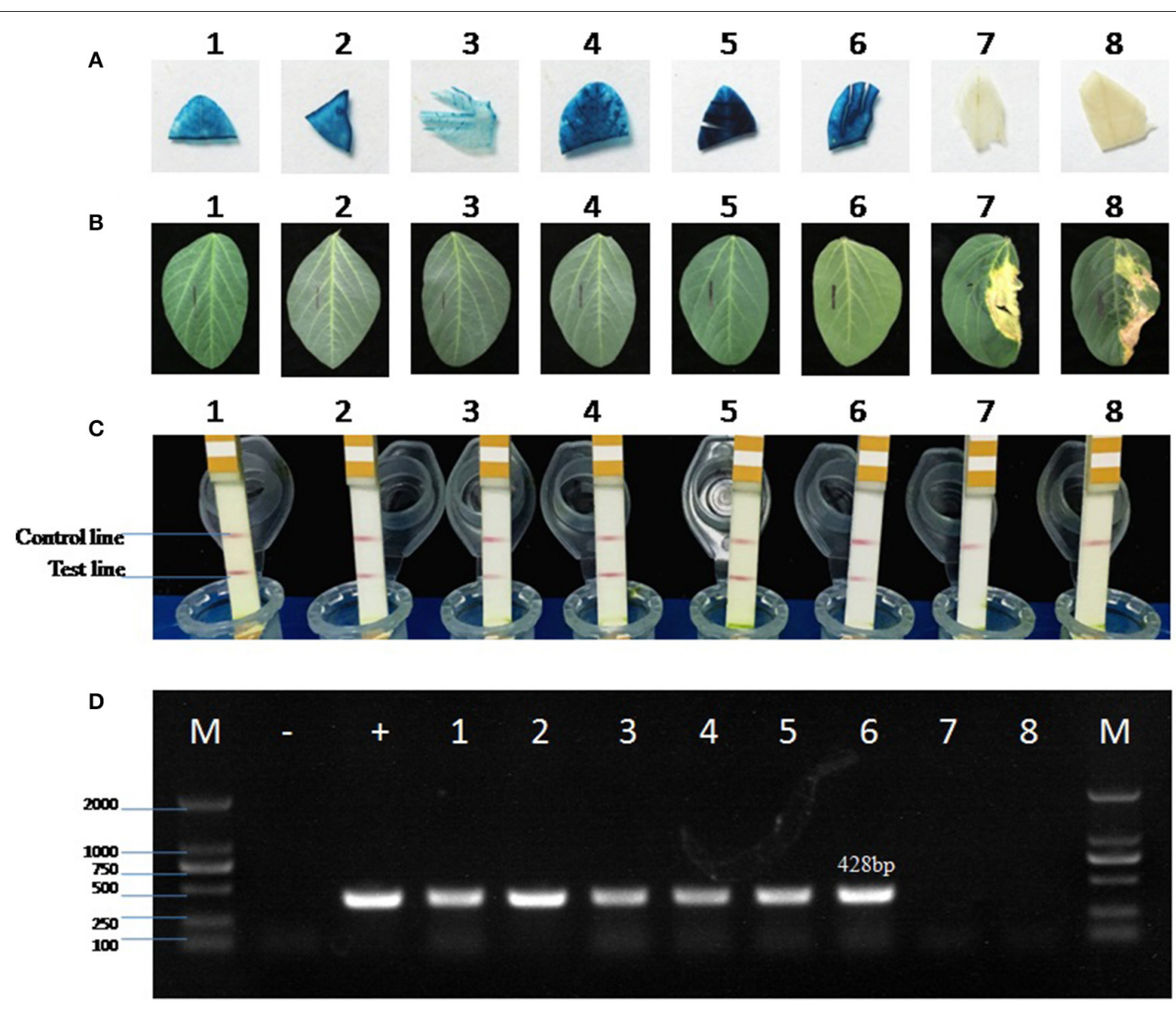

FIGURE 10 | Detection of the positive transgenic soybean plants. (A) GUS staining of soybean leaves. (B) Herbicide (glufosinate) painting on soybean leaves. The left was marked by a black line as control, and the right was painted by $135 \mathrm{mg} / \mathrm{L}$ glufosinate. (C) Liberty Link ${ }^{\circledR}$ strip detection. The first line is control line, and the second line is test line. (D) PCR amplification of the 428-bp bar gene fragment using negative control (-, ddH $\left.{ }_{2} \mathrm{O}\right)$, positive control (+, plasmid pTF102), or soybean genomic DNA as the template. M, 2000 bp DNA marker. 1-3, positive transgenic soybean plants in Jack Purple background. 4-6, positive transgenic soybean plants in Tianlong 1 background. 7, negative control of Jack Purple. 8, negative control of Tianlong 1.

It has been reported in other plant spices that the optimum concentration of $\mathrm{GA}_{3}$ and IAA in SEM could improve the rate of shoot elongation effectively (Gonbad et al., 2014). We investigated six different concentration combinations of $\mathrm{GA}_{3}$ and IAA in SEM, and the highest rate of shoot elongation was achieved (33.54\% in Jack Purple and $26.08 \%$ in Tianlong 1) when $1.0 \mathrm{mg} / \mathrm{L} \mathrm{GA}_{3}$ and $0.1 \mathrm{mg} / \mathrm{L}$ IAA were added in SEM (Table 1). A previous study showed that a higher elongation rate was observed when adding $0.5 \mathrm{mg} / \mathrm{L} \mathrm{GA}_{3}$ without IAA in SEM when using the soybean variety Heinong 35 explants (Li et al., 2008a). In another study, the highest shoot elongation rate was obtained by adding 1 $\mathrm{mg} / \mathrm{L} \mathrm{GA}_{3}$ and $0.5 \mathrm{mg} / \mathrm{L} \mathrm{IAA}$ to SEM for soybean variety Jiyu 47 (Sun, 2013). These results suggest that the optimal concentration combination of $\mathrm{GA}_{3}$ and IAA in SEM varies among different soybean genotypes.

Plants will generate reactive oxygen species upon the infection of Agrobacterium, which leads to cell death and tissue browning. Low concentrations of antioxidants can prevent cell necrosis and improve the transformation efficiency. In this study, the rate of strong GUS transient expression in the cotyledonary explants of Jack Purple and Tianlong 1 increased by 16 and $35 \%$, respectively, after adding the antioxidant DTT in CCM (Figure 4). The previous study showed that adding $\mathrm{Vc}$ in the medium can reduce the degree of tissue browning significantly, and the addition of $\mathrm{AgNO}_{3}$ can not only reduce tissue browning effectively, but also improve the regeneration efficiency and the number of shoots significantly (Huang et al., 2006). However, in our experiment, the addition of $\mathrm{AgNO}_{3}$ or Vc in SIM and SEM did not reduce the browning of the explants. Adding 15 $\mathrm{mg} / \mathrm{L} \mathrm{AgNO}_{3}$ in SIM and SEM improved the rate of shoot elongation and transformation efficiency in 88-1 (Table S3), and slightly increased the shoot elongation rate in Tainlong 1, but reduced the rate of shoot elongation and transformation efficiency in Jack Purple (Table 2). Adding $200 \mathrm{mg} / \mathrm{L} \mathrm{Vc}$ in SIM and SEM only slightly increased the rate of shoot elongation when $\mathrm{GA}_{3}$ was $0.5 \mathrm{mg} / \mathrm{L}$ but not at $1 \mathrm{mg} / \mathrm{L} \mathrm{GA} \mathrm{G}_{3}$ for Jack Purple and Tianlong 1 (Table 3). Therefore, the effect of $\mathrm{AgNO}_{3}$ and $\mathrm{Vc}$ on the shoot elongation rate and transformation efficiency would depend on soybean genotype and $\mathrm{GA}_{3}$ concentration. 
TABLE 5 | The copy number of bar gene in $\mathrm{T}_{1}$ transgenic soybean plants.

\begin{tabular}{lcccc}
\hline Sample $^{\mathbf{a}}$ & $\mathbf{C}_{\mathbf{t}, \mathbf{X}}^{\mathbf{b}}$ & $\mathbf{C}_{\mathbf{t}, \mathbf{R}}^{\mathbf{c}}$ & $\begin{array}{c}\text { Ratio of bar/lectin } \\
\left(\mathbf{X}_{\mathbf{0}} / \mathbf{R}_{\mathbf{0}}\right)^{\mathbf{d}}\end{array}$ & $\begin{array}{c}\text { Copy number } \\
\text { of bar gene }\end{array}$ \\
\hline 1 & $26.94 \pm 0.12$ & $20.52 \pm 0.00$ & 3.10 & 3 \\
2 & $26.24 \pm 0.39$ & $20.78 \pm 0.56$ & 1.55 & 2 \\
3 & $26.74 \pm 0.11$ & $20.17 \pm 0.21$ & 1.42 & 1 \\
4 & $25.51 \pm 0.24$ & $21.58 \pm 0.09$ & 1.56 & 2 \\
5 & $24.39 \pm 0.17$ & $21.52 \pm 0.23$ & 3.42 & 3 \\
6 & $26.54 \pm 0.08$ & $21.85 \pm 0.15$ & 0.88 & 1 \\
\hline
\end{tabular}

a 1-3, positive $T_{1}$ transgenic soybean plants in Jack Purple background. 4-6, positive $T_{1}$ transgenic soybean plants in Tianlong 1 background.

${ }^{b} C_{t, X}$ represents the $C t$ value of the exogenous target gene (bar).

${ }^{c} C_{t, R}$ represents the $C t$ value of the internal reference gene (lectin).

${ }^{d} X_{0} / R_{0}$ is the ratio of initial amount of bar/lectin. $X_{0} / R_{0}=10[([C t, X-\mid X) / S X]-[(C t, R-I R) / S R]$, where $I X$ and $S X$ is the intercept and slope of the standard curve of the target bar gene, respectively, and IR and SR is the intercept and slope of the standard curve of the reference lectin gene, respectively.

In this study, we used four different methods to detect the positive transgenic plants, including GUS histochemical staining, PCR amplification of exogenous gene, herbicide (glufosinate) painting, and LibertyLink ${ }^{\circledR}$ strip detection. GUS staining during rooting stage is recommended to identify positive transgenic plants, which can reduce labor intensity by eliminating negative plants as soon as possible, and herbicide painting would be an easy and reliable method to confirm the results. GUS staining after transplanting might miss the detection of some positive plants, which is likely due to the fact that older leaves are difficult to get stained.

Southern blot has been a traditional method to detect the copy number of exogenous gene in transgenic plants, which gives us highly precise and intuitive results, but complex operations and large amounts of plant material are required. Absolute quantitative PCR technology provides a new approach to detect the copy number of integrated exogenous gene in transgenic plants (Ingham et al., 2001; Weng et al., 2004), which has many advantages such as lower cost, simple operation, high sensitivity and stability, and has been successfully applied to cotton (Yang, 2012), wheat (Gadaleta et al., 2011), rice (Wei et al., 2011), maize (Yuan et al., 2010), tomato (Wang et al., 2011), and soybean (Qiu et al., 2012). In this study, we used absolute quantitative PCR to detect the copy number of exogenous gene (bar) in the $\mathrm{T}_{1}$ generation of transgenic soybean plants, and the results showed that the copy number of bar gene ranged from one to three. The copy number of exogenous gene in transgenic plants affects the expression level and genetic stability of the exogenous gene. The integration of multiple copies of exogenous DNA into one or more chromosomes might result in low gene expression level, low genetic stability, or even gene silencing (Iyer and Kumpatla, 2000; James et al., 2002). The ideal copy number of target gene in transgenic plants is generally one or two (Tang et al., 2007). In this study, four out of six (67\%) transgenic plants contained low copy numbers (one or two), which suggests that the Agrobacterium-mediated transformation is a preferred method for soybean transformation.

\section{CONCLUSION}

In this study, the Agrobacterium-mediated transformation efficiency in soybean was improved by increasing both Agrobacterium infection efficiency and explant regeneration efficiency. The Agrobacterium infection efficiency was more than 96\% when collecting the Agrobacterium at a concentration of $\mathrm{OD}_{650}=0.6$, then re-suspended in liquid CCM containing 154.2 $\mathrm{mg} / \mathrm{L}$ DTT to infect the half-seed cotyledonary explants (from mature seeds imbibed for 1 day), and co-cultured them for 5 days, using the soybean varieties of Jack Purple or Tianlong 1. The shoot elongation rate of Jack Purple and Tianlong 1 increased to 33.54 and $26.08 \%$ when $1.0 \mathrm{mg} / \mathrm{L} \mathrm{GA}_{3}$ and $0.1 \mathrm{mg} / \mathrm{L}$ IAA were added to SEM, which is almost twice of the previous shoot elongation rate (16.11 and $14.75 \%$ for Jack Purple and Tianlong 1 , respectively) with $0.5 \mathrm{mg} / \mathrm{L} \mathrm{GA}_{3}$ and $0.1 \mathrm{mg} / \mathrm{L}$ IAA in SEM. Ultimately, the transformation efficiency was improved from 5.00 to $7.32 \%$ and 4.28 to $10.01 \%$ for Jack Purple and Tianlong 1, respectively. This study provides an optimized Agrobacteriummediated transformation protocol for soybean varieties of Jack Purple and Tianlong 1, and would be a useful reference for improving transformation efficiencies in other plant species.

\section{AUTHOR CONTRIBUTIONS}

SL, YC, and YLi conceived and designed the experiments. SL, YC, YLiu, TW, QS, and NC performed the experiments. SL, YC, and YLi analyzed the data. SL, YC, and YLi generated the pictures. SL and YLi wrote and revised the manuscript. JG and YLi contributed reagents/materials and interpretation of the results. All authors read, revised and approved the final manuscript.

\section{FUNDING}

This work was supported by the Key Transgenic Breeding Program of China (2014ZX0801005B), the National Natural Science Foundation of China (31371645), the Fundamental Research Funds for the Central Universities, the Program for Changjiang Scholars and Innovative Research Team in University (PCSIRT13073), the MOE 111 Project (B08025), the Program for MOA Innovative Research Team, and the Program for High-level Innovative and Entrepreneurial Talents in Jiangsu Province.

\section{ACKNOWLEDGMENTS}

We are very grateful to Dr. Huixia Shou (Zhejiang University, China) for her valuable discussion and giving us the A. tumefaciens strain EHA101, and thank Dr. Kan Wang (Iowa State University, USA) for kindly providing us the binary plasmid pTF102.

\section{SUPPLEMENTARY MATERIAL}

The Supplementary Material for this article can be found online at: http://journal.frontiersin.org/article/10.3389/fpls.2017. 00246/full\#supplementary-material 


\section{REFERENCES}

Almqvist, C. (2003). Timing of GA4/7 application and the flowering of Pinus sylvestris grafts in the greenhouse. Tree Physiol. 23, 413-418. doi: 10.1093/treephys/23.6.413

An, G., Ebert, P. R., Mitra, A., and Ha, S. B. (1989). "Binary vectors," in Plant Molecular Biological Manual, eds S. B. Gelvin, R. A. Schilperoort, and D. P. Verma (Dordrecht: Springer Netherlands; Kluwer Academic Publishers), 29-47. doi: 10.1007/978-94-009-0951-9_3

An, X., Wang, B., Liu, L., Jiang, H., Chen, J., Ye, S., et al. (2014). Agrobacteriummediated genetic transformation and regeneration of transgenic plants using leaf midribs as explants in ramie [Boehmeria nivea (L.) Gaud]. Mol. Biol. Rep. 41, 3257-3269. doi: 10.1007/s11033-014-3188-4

Bailey, M. A., and Parrott, W. A. (1993). Genotype effects on proliferative embryogenesis and plant regeneration of soybean. In Vitro Cell. Dev. Biol. Plant 29, 102-108. doi: 10.1007/BF02632279

Dan, Y. (2008). Biological functions of antioxidants in plant transformation. In Vitro Cell. Dev. Biol. Plant 44, 149-161. doi: 10.1007/s11627-008-9110-9

Dan, Y. H., Armstrong, C. L., Dong, J., Feng, X. R., Fry, J. E., Keithly, G. E., et al. (2009). Lipoic acid-an unique plant transformation enhancer. In Vitro Cell. Dev. Biol. Plant 45, 630-638. doi: 10.1007/s11627-009-9227-5

Di, R., Purcell, V., Collins, G. B., and Ghabrial, S. A. (1996). Production of transgenic soybean lines expressing the bean pod mottle virus coat protein precursor gene. Plant Cell Rep. 15, 746-750. doi: 10.1007/BF00 232220

Donaldson, P. A., and Simmonds, D. H. (2000). Susceptibility to Agrobacterium tumefaciens and cotyledonary node transformation in short-season soybean. Plant Cell Rep. 19, 478-484. doi: 10.1007/s002990050759

Dong, S., Zhang, Y., Lv, M., Yang, F., Gao, Y., and Wang, H. (2011). Advances problems and break through direction of plant transgenic technique. J. Hebei. Agric. 15, 57-65. doi: 10.3969/j.issn.1088-1631.2011.03.019

Enríquez Obregó, G. A., Vázquez Padrón, R. I., Prieto-Samsonov, D. L., Riva, G. A. D. L., and Selman Housein, G. (1998). Herbicide-resistant sugarcane (Saccharum officinarum L.) plants by Agrobacterium -mediated transformation. Planta 206, 20-27. doi: 10.1007/s004250050369

Frame, B. R., and Kan, W. (2002). Agrobacterium tumefaciens-mediated transformation of maize embryos using a standard binary vector system. Plant Physiol. 129, 13-22. doi: 10.1104/pp.000653

Gadaleta, A., Giancaspro, A., Cardone, M. F., and Blanco, A. (2011). Real-time PCR for the detection of precise transgene copy number in durum wheat. Cell. Mol. Biol. Lett. 16, 652-668. doi: 10.2478/s11658-011-0029-5

Gamborg, O. L., and Al, E. (1968). Nutrient requirements of suspension cultures of soybean root cells. Exp. Cell Res. 50, 151-158. doi: 10.1016/0014-4827(68)90403-5

Gao, L., Ding, X., Li, K., Liao, W., Zhong, Y., Ren, R., et al. (2015). Characterization of Soybean mosaic virus resistance derived from inverted repeat-SMV-HCPro genes in multiple soybean cultivars. Theor. Appl. Genet. 128, 1489-1505. doi: 10.1007/s00122-015-2522-0

Ge, X., Chu, Z., Lin, Y., and Wang, S. (2006). A tissue culture system for different germplasms of indica rice. Plant Cell Rep. 25, 392-402. doi: 10.1007/s00299-005-0100-7

Gnasekaran, P., Antony, J. J. J., Uddain, J., and Subramaniam, S. (2014). Agrobacterium-mediated transformation of the recalcitrant vanda kasem's delight orchid with higher efficiency. Sci. World J. 2014:583934. doi: 10.1155/2014/583934

Gonbad, R. A., Rani, S. U., Aziz, M. A., and Mohamad, R. (2014). Influence of cytokinins in combination with $\mathrm{GA}_{3}$ on shoot multiplication and elongation of tea clone Iran 100 (Camellia sinensis (L.) O. Kuntze). Sci. World J. 5, 149-168. doi: 10.1155/2014/943054

Han, L., Gai, J., and Zhang, W. (2003). The present study of soybean nutrients. Seed 131, 57-59. doi: 10.3969/j.issn.1001-4705.2003.05.023

Hinchee, M. A. W., Connor-Ward, D. V., Newell, C. A., Mcdonnell, R. E., Sato, S. J., Gasser, C. S., et al. (1988). Production of transgenic soybean plants using agrobacterium-mediated dna transfer. Nat. Biotechnol. 6, 915-922. doi: 10.1038/nbt0888-915

Hood, E. E., Helmer, G. L., Fraley, R. T., and Chilton, M. D. (1986). The hypervirulence of Agrobacterium tumefaciens A281 is encoded in a region of pTiBo542 outside of T-DNA. J. Bacteriol. 168, 1291-1592. doi: $10.1128 /$ jb.168.3.1291-1301.1986
Hua, W. Y., and Irving, H. R. (2011). Developing a model of plant hormone interactions. Plant Signal. Behav. 6, 494-500. doi: 10.4161/psb.6.4.14558

Huang, J., Ma, F., Fan, J., Li, X., and Tong, J. (2006). In vitro plant regeneration with adventitious buds of Zizyphus jujuba leaves. Acta Bot. Boreali-Occidentalia Sinica 26, 942-948. doi: 10.3321/j.issn:1000-4025.2006.05.012

Ingham, D. J., Beer, S., Money, S., and Hansen, G. (2001). Quantitative real-time PCR assay for determining transgene copy number in transformed plants. BioTechniques 31, 136-140.

Ishida, Y., Saito, H., Ohta, S., Hiei, Y., Komari, T., and Kumashiro, T. (1996). High efficiency transformation of maize (Zea mays L.) mediated by Agrobacterium tumefaciens. Nat. Biotechnol. 14, 745-750. doi: 10.1038/nbt0696-745

Iyer, L. M., and Kumpatla, S. P. (2000). Transgene silencing in monocots. Plant Mol. Biol. 43, 323-346. doi: 10.1023/A:1006412318311

James, V. A., Avart, C., Worland, B., Snape, J. W., and Vain, P. (2002). The relationship between homozygous and hemizygous transgene expression levels over generations in populations of transgenic rice plants. Theor. Appl. Genet. 104, 553-561. doi: 10.1007/s001220100745

Jefferson, R. A., Kavanagh, T. A., and Bevan, M. W. (1987). GUS fusions: betaglucuronidase as a sensitive and versatile gene fusion marker in higher plants. EMBO J. 6, 3901-3907.

Ji, L., and Yang, R. (2002). Rice stem elongation and plant hormones. Chin. Bull. Bot. 19, 109-115. doi: 10.3969/j.issn.1674-3466.2002.01.016

Kim, J. H., Lamotte, C. E., and Hack, E. (1990). Plant regeneration in vitro from primary leaf nodes of soybean (Glycine max) seedlings. J. Plant Physiol. 136, 664-669. doi: 10.1016/S0176-1617(11)81341-6

Kumari, U., Vishwakarma, R. K., Gupta, N., Ruby, Shirgurkar, M. V., and Khan, B. M. (2015). Efficient shoots regeneration and genetic transformation of Bacopa monniera. Physiol. Mol. Biol. Plants 21, 261-267. doi: 10.1007/s12298-015-0290-6

Letham, D. S. (1967). Regulators of cell division in plant tissues: V. A comparison of the activities of zeatin and other cytokinins in five bioassays. Planta 74, 228-242. doi: 10.1016/s0040-4020(01)83332-9

Li, W., Li, W., Lv, W., and Ning, H. (2008a). Break through of two questions on the agrobacterium-mediated soybean cotyledonary node systems. Soybean Sci. 27, 173-175. doi: 10.11861/j.issn.1000-9841.2008.01.0173

Li, W., Ning, H., Lv, W., and Li, W. (2008b). Optimization of the agrobacteriummediated transformation systems of soybean cotyledonary node. Sci. Agric. Sin. 41, 971-977. doi: 10.3864/j.issn.0578-1752.2008.04.005

Lin, Y. J., and Zhang, Q. (2005). Optimising the tissue culture conditions for high efficiency transformation of indica rice. Plant Cell Rep. 23, 540-547. doi: 10.1007/s00299-004-0843-6

Liu, H. K., Yang, C., and Wei, Z. M. (2004). Efficient Agrobacterium tumefaciensmediated transformation of soybeans using an embryonic tip regeneration system. Planta 219, 1042-1049. doi: 10.1007/s00425-004-1310-x

Liu, Z., Shan, L., Xu, P., Li, G., and Xiuli, W. (2001). Advances in genetic transformation of graminaceous crops by particle bombardment. J. Shenyang Agric. Univ. 32, 465-468. doi: 10.1007/s00425-004-1310-x

Masekesa, R. T., Gasura, E., Matikiti, A., Kujeke, G. T., Ngadze, E., Icishahayo, D., et al. (2016). Effect of BAP, NAA and GA3, either alone or in combination, on meristem culture and plantlet establishment in sweet potato (cv Brondal). Afr. J. Food Agric. Dev. 16, 10653-10669. doi: 10.18697/ajfand.73.15875

Mccabe, D. E., Swain, W. F., Martinell, B. J., and Christou, P. (1988). Stable transformation of soybean (Glycine Max) by particle acceleration. Nat. Biotechnol. 6, 923-926. doi: 10.1038/nbt0888-923

Murashige, T., and Skoog, F. (1962). A revised medium for rapid growth and bio assays with tobacco tissue cultures. Physiol. Plant. 15, 473-497. doi: 10.1111/j.1399-3054.1962.tb08052.x

Nishijima, T., Katsura, N., Koshioka, M., Yamazaki, H., and Mander, L. N. (1997). Effects of uniconazole and GA3 on cold-induced stem elongation and flowering of Raphanus sativus L. Plant Growth Regul. 21, 207-214. doi: 10.1023/A:1005806107254

Normanly, J. (1997). Auxin metabolism. Physiol. Plant. 100, 431-442. doi: 10.1111/j.1399-3054.1997.tb03047.x

Olhoft, P., and Somers, D. (2001). L-Cysteine increases Agrobacterium -mediated T-DNA delivery into soybean cotyledonary-node cells. Plant Cell Rep. 20, 706-711. doi: 10.1007/s002990100379

Paterson, A. H., Brubaker, C. L., and Wendel, J. F. (1993). A rapid method for extraction of cotton (Gossypium Spp.) genomic DNA suitable for RFLP or PCR analysis. Plant Mol. Bio. Rep. 11, 122-127. doi: 10.1007/BF02670470 
Paz, M. M., Martinez, J. C., Kalvig, A. B., Fonger, T. M., and Wang, K. (2006). Improved cotyledonary node method using an alternative explant derived from mature seed for efficient Agrobacterium-mediated soybean transformation. Plant Cell Rep. 25, 206-213. doi: 10.1007/s00299-005-0048-7

Peng, X., Yi, Z., JIang, J., and Liu, L. (2007). Perliminary studies on anti-browning during the tissue culture of bromeliaceae. Hunan Agric. Sci. 67-69. doi: 10. 16498/j.cnki.hnnykx

Qi, W., Tinnenbroek-Capel, I. E., Schaart, J. G., Huang, B., Cheng, J., Visser, R. G., et al. (2014). Regeneration and transformation of Crambe abyssinica. BMC Plant Biol. 14:235. doi: 10.1186/s12870-014-0235-1

Qiu, Y. W., Gao, X. J., Qi, B. R., Li, L., and Zhen, Z. (2012). Establishment of taqman real-time quantitative pcr assay for foreign gene copy numbers in transgenic soybean. J. Northeast Agric. Univ. 19, 48-52. doi: 10.1016/S1006-8104(13)60050-1

Ren, H., Nan, H., Cao, D., Liu, X., Liu, B., and Kong, F. (2012). Progress and perspective on soybean genetic transformation. J. Northeast Agric. Univ. 43, 6-12.

Sambrook, J. F. and Russell, D. W. (2001). Molecular Cloning: A Laboratory Manual. New York, NY: Cold Spring Harbour Laboratory Press.

Sato, S., Newell, C., Kolacz, K., Tredo, L., Finer, J., and Hinchee, M. (1993). Stable transformation via particle bombardment in two different soybean regeneration systems. Plant Cell Rep. 12, 408-413. doi: 10.1007/bf00234702

Schmutz, J., Cannon, S. B., Schlueter, J., Ma, J., Mitros, T., Nelson, W., et al. (2010). Genome sequence of the palaeopolyploid soybean. Nature 463, 178-183. doi: $10.1038 /$ nature 08670

Shou, H., Palmer, R. G., and Wang, K. (2002). Irreproducibility of the Soybean pollen-tube pathway transformation procedure. Plant Mol. Biol. Rep. 20, 325-334. doi: 10.1007/BF02772120

Skoog, F., and Miller, C. O. (1957). Chemical regulation of growth and organ formation in plant tissues cultured in vitro. Symp. Soc. Exp. Biol. 11, 118-130.

Song, Z., Tian, J., Fu, W., Li, L., Lu, L., Zhou, L., et al. (2013). Screening chinese soybean genotypes for agrobacterium-mediated genetic transformation suitability. J. Zhejiang Univ. Sci. B. 14, 289-298. doi: 10.1631/jzus.B1200278

Sun, X. (2013). Establishment and Optimization of Soybean Cotyledonary-Node Genetic Transformation System of Jiyu47. Thesis, Jilin University Press.

Tang, W., Newton, R. J., and Weidner, D. A. (2007). Genetic transformation and gene silencing mediated by multiple copies of a transgene in eastern white pine. J. Exp. Bot. 58, 545-554. doi: 10.1093/jxb/erl228

Thomas, S. G., and Sun, T. (2004). Update on gibberellin signaling. a tale of the tall and the short. Plant Physiol. 135, 668-676. doi: 10.1104/pp.104.040279

Tiwari, V., Chaturvedi, A. K., Mishra, A., and Jha, B. (2015). An efficient method of agrobacterium-mediated genetic transformation and regeneration in local Indian cultivar of groundnut (Arachis hypogaea) using grafting. Appl. Biochem. Biotechnol. 175, 436-453. doi: 10.1007/s12010-014-1286-3

Vodkin, L. O., Rhodes, P. R., and Goldberg, R. B. (1983). cA lectin gene insertion has the structural features of a transposable element. Cell 34, 1023-1031. doi: 10.1016/0092-8674(83)90560-3

Wang, G., and Huang, M. (2002). Tissue culture and plant regeneration of cerasus campanulata. J. Nanjing Univ. 26, 73-76. doi: 10.3969/j.issn.1000-2006.2002. 02.019

Wang, G. L., and Xu, Y. N. (2008). Hypocotyl-based Agrobacterium-mediated transformation of soybean (Glycine max) and application for RNA interference. Plant Cell Rep. 27, 1177-1184. doi: 10.1007/s00299-008-0535-8

Wang, G., Sun, Y., Na, J., Li, H., and Fang, H. (2006). Progress and problems of commercial production to transgenic plants in china. Sci. Agric. Sin. 39, 1328-1335. doi: 10.3321/j.issn:0578-1752.2006.07.005

Wang, G., Wang, P., Lin, Y., Zhang, L., and Wu, Y. (2002). The studies of sensitivity of genotypes in soybean to lines of Agrobacterium tumefaciens. Heresitas 24, 297-300. doi: 10. 16288/ j.yczz.2002.03.018

Wang, W., Zhu, C., Liu, X., Chen, K., and Xu, C. (2011). Techniques for rapid preparation of tomato leaf DNA and its application in realtime quantitative PCR-based transgene detection. Hereditas 33, 1017-1022. doi: 10.3724/SP.J.1005.2011.01017

Wang, X., Liu, S., and Luo, Y. (2009). Research progression soybean tissue culture system and transformation. Soybean Sci. 28, 731-735. doi: 10.11861/j.issn.1000-9841.2009.04.0731

Wei, J., Chen, S., Zeng, L., Yang, J., Liu, X., and Zhu, X. (2011). Quantitative expression analysis of rice bacterial blight resistant candidate genes of Xa7 by real-Time fluorescent quantitative PCR. Mol. Plant Breed. 9, 9-16. doi: $10.3969 / \mathrm{mpb} .009 .000009$
Weng, H., Pan, A., Yang, L., Zhang, C., Liu, Z., and Zhang, D. (2004). Estimating number of transgene copies in transgenic rapeseed by real-time PCR assay with HMG I/Y as an endogenous reference gene. Plant Mol. Biol. Rep. 22, 289-300. doi: 10.1007/BF02773139

Wu, X., Li, W., and Zhang, S. (2005). The research progress of transgenic soybean in china. Soybean Sci. 24, 144-149. doi: 10.3969/j.issn.1000-9841.2005.02.013

Xiao, R. G., Guo, K. W., Qiao, S., Yan, W., and Li, J. A. (2007). Phytase expression in transgenic soybeans: stable transformation with a vector-less construct. Biotechnol. Lett. 29, 1781-1787. doi: 10.1007/s10529-007-9439-x

$\mathrm{Xu}, \mathrm{M} ., \mathrm{Li}, \mathrm{Y}$., and Wu, J. (2010). Comparative analysis of tissue culture efficiency in four varieties in limonium. Northern Hortic. 2, 157-160.

Yang, A., He, C., and Zhang, K. (2006). Improvement of Agrobacterium-mediated transformation of embryogenic calluses from maize elite inbred lines. In Vitro Cell Dev. Biol. Plant 42, 215-219. doi: 10.1079/IVP2006768

Yang, J., Xing, G., Du, Q., Sui, L., Guo, D., Niu, L., et al. (2016). Effects of different soybean genotypes on the transformation efficiency of soybean and analysis of the t-dna insertions in the soybean genome. Soybean Sci. 35, 562-567. doi: 10.11861/j.issn.1000-9841.2016.04.0562

Yang, X. (2012). Analysis of the copy number of exogenous genes in transgenic cotton using real-time quantitative PCR and the $2^{-\Delta \Delta C T}$ method. Afr. J. Biotechnol. 11, 6226-6233. doi: 10.5897/AJB11.4117

Yang, X., Sui, L., Li, Q., Yang, J., XIng, G., Guo, D., et al. (2012). Recent advances in soybean transformation. Soybean Sci 31, 302-310. doi: 10.3969/j.issn.1000-9841.2012.02.031

Yu, H., Xia, G., and Hou, B. (2005). Factors improving the efficiency of wheat transformation mediated by Agrobacterium tumefaciens. J. Shandong Univ. 40, 120-124. doi: 10.3969/j.issn.1671-9352.2005.06.026

Yu, Y., Liang, H., Wang, S., Lian, Y., Wei, Y., and Wang, T. (2010). Research progress and commercialization on transgenic soybean in china. Soybean Sci. 29, 143-150. doi: 10.11861/j.issn.1000-9841.2010.01.0143

Yuan, L., Sun, H., Yang, C., Shang, Y., Lu, X., and Zhao, L. (2010). Analysis of junction sequence in the transgenic maize MON88017 and the methods of qualitative PCR detection. Acta Agron. Sin. 36, 361-364. doi: 10.3724/SP.J.1006.2010.00361

Yukika, Y., Mikihiro, O., Ayuko, K., Atsushi, H., Yuji, K., and Shinjiro, Y. (1997). Activation of gibberellin biosynthesis and response pathways by low temperature during imbibition of Arabidopsis thaliana seeds. Lung Cancer 18, 367-378.

Zhang, J., Zhao, T., Zheng, W., Shang, L., Wang, Y., Qiu, L., et al. (2016). Genetic transformation of soybean with resistance gene GmUBC2 and the identification of resistant materials. J. Agric. Univ. Hebei. 39, 106-116. doi: 10.13320/j.cnki.jauh.2016.0043

Zhang, Z. Y., Xing, A. Q., Staswick, P., and Clemente, T. E. (1999). The use of glufosinate as a selective agent in Agrobacterium-mediated transformation of soybean. Plant Cell Tiss Org 56, 37-46. doi: 10.1023/A:10062986 22969

Zhong, G. (2007). Establishment of High Efficient Regenration System of Lilium and Agrobacterium-mediated Genetic Transformation. Thesis, Southwest University Press.

Zhong, H., and Que, Q. (2009). Method for Transforming Soybean (Glycine max). United States Patent: US 20090023212.

Zhou, G. Y., Weng, J., Zeng, Y., Huang, J., Qian, S., and Liu, G. (1983). Introduction of exogenous DNA into cotton embryos. Method Enzymol. 101, 433-481. doi: 10.1016/0076-6879(83)01032-0

Zhou, J., Wang, C., Liu, X., and Tan, Y. (2011). A study on improving regeneration rate of agrobacterium-mediated callus of mature embryo for indica rice. Chin. Agric. Sci. Bull. 27, 1-5.

Conflict of Interest Statement: The authors declare that the research was conducted in the absence of any commercial or financial relationships that could be construed as a potential conflict of interest.

Copyright (c) 2017 Li, Cong, Liu, Wang, Shuai, Chen, Gai and Li. This is an openaccess article distributed under the terms of the Creative Commons Attribution License (CC BY). The use, distribution or reproduction in other forums is permitted, provided the original author(s) or licensor are credited and that the original publication in this journal is cited, in accordance with accepted academic practice. No use, distribution or reproduction is permitted which does not comply with these terms. 